$9-1-2015$

\title{
Changing Course in the Anti-Domestic Violence Legal Movement: From Safety to Security
}

Margaret E. Johnson

Follow this and additional works at: https://digitalcommons.law.villanova.edu/vlr

Part of the Law Commons

\section{Recommended Citation}

Margaret E. Johnson, Changing Course in the Anti-Domestic Violence Legal Movement: From Safety to Security, 60 Vill. L. Rev. 145 (2015).

Available at: https://digitalcommons.law.villanova.edu/vlr/vol60/iss1/4

This Article is brought to you for free and open access by Villanova University Charles Widger School of Law Digital Repository. It has been accepted for inclusion in Villanova Law Review by an authorized editor of Villanova University Charles Widger School of Law Digital Repository. 


\title{
CHANGING COURSE IN THE ANTI-DOMESTIC VIOLENCE LEGAL MOVEMENT: FROM SAFETY TO SECURITY
}

\author{
Margaret E. Johnson*
}

"[In the field of cybersecurity] [r] esilience is what allows a system to endure security threats instead of critically failing. A key to resilience is accepting the inevitability of threats and even limited failures in your defenses. It is about remaining operational with the understanding that attacks and incidents happen on a continuous basis. ... [T] he objective should be to prioritize resources and operations, protect key assets and systems from attacks, and ultimately restore normal operations." ${ }^{1}$

\section{MARY}

$\mathrm{M}$ ARY $^{2}$ met Todd in Florida. Todd moved back to his home state of Washington, D.C.; after a few months, he asked her to come and join him. Although she had no family or friends in D.C., Mary followed Todd willingly. She loved Todd and, flat broke and unsuccessful in finding a job in Florida, hoped she would have better prospects up north.

After Mary moved in with Todd, however, he would not let her look for a job. He would not let her out of the house without his permission. If he thought she had done something that was against the many rules he established for the household, he would hit her. He told her that if she ever left, he would find her. She had no access to people or a telephone. Mary's necessary medicine for her long-term illness ran out, but Todd refused to let her refill the prescription. As the days went on, she got more and more sick. She knew she needed to get out and get to a hospital.

* Associate Professor, Director, Family Law Clinic, and Co-Director, Center on Applied Feminism, University of Baltimore School of Law. I appreciate the comments I have received on this piece during the UB Law Faculty Research and Development Series, the Law and Society Annual Meeting, the Converge! Conference at the University of Miami Law School, and the Clinical Law Review Writing Workshop at NYU Law School. Special thanks to Dionne Koller, Michele Gilman, Leigh Goodmark, Karen Czapanski, Donna Coker, Margaret Drew, Phyllis Goldfarb, James Ptacek, Fred Brown, and Mae Quinn. I especially thank Matt Fraidin for his amazing assistance in helping me think through the ideas in this Article. I am grateful to my research assistants Lana Castor, Amy Lazas, Nicole Whitaker, and Addie Crawford, and the University of Baltimore Law Library staff, including David Matchen, Bijal Shah, and Adeen Postar. I appreciate the support of the University of Baltimore School of Law Summer Research Fellowship. All errors are of course mine.

1. P.W. Singer \& Allan Friedman, Cybersecurity and Cyberwar: What EveRYONe NeEds To Know 36 (2014).

2. Mary is a fictional name, but her story is based on the experiences of a client in my law clinic. 
One day when Todd left the home to run an errand, Mary quickly left the house and asked a stranger to take her to a hospital. The hospital discharged Mary after treating her for a week.

Homeless, penniless, and afraid to return to Todd, Mary sought and won a temporary protective order and with that successfully applied for a thirty-day stay in an emergency shelter. Two weeks later, the court issued a one-year order that enjoined Todd from further abusing her, coming near her, or contacting her. Both orders gave Mary the power to call the police to enforce them through arrest and criminal prosecution. ${ }^{3}$

While in the shelter, Mary received limited transportation vouchers. The vouchers covered her travel from the distant shelter to the court, but they did not cover her travel to the library where she wanted to apply for jobs on the computer, to a nonprofit organization offering professional attire she wanted for her job interviews, or to the job interviews she obtained. She accessed meager emergency grocery-store vouchers, with which she purchased food and personal items not provided by the shelter, such as toilet paper and tampons. When Mary's thirty-day emergency shelter time came to an end, she could not access any long-term housing because it was in short supply. She no longer had her transportation or food vouchers. With no money of her own, and feeling like she had no other option, Mary reluctantly returned to Todd.

\section{INTRODUCTION}

Protection of women in the name of safety from domestic violence has gone too far. This Article argues that domestic violence law and practice overemphasize women's short-term safety in ways that deprive women

3. But see, e.g., Town of Castle Rock, Colo. v. Gonzales, 545 U.S. 748, 768 (2005) (holding that, under U.S. Constitution's Due Process Clause, wife had no constitutionally protected property interest in police enforcement of her restraining order against her husband). Subsequent to the Supreme Court's decision, Ms. Lenahan (formerly Gonzales) brought a successful claim of human rights violations under the American Declaration on the Rights and Duties of Man against the Castle Rock Police Department for failing to protect her and her children, who were in fact killed by her estranged husband during the pendency of her protective order, and human rights violations by the U.S. courts for failing to remedy her situation. See Caroline Bettinger-Lopez, Introduction: Jessica Lenahan (Gonzales) v. United States: Implementation, Litigation, and Mobilization Strategies, 21 Am. U. J. Gender Soc. Pol'y \& L. 207, 219-20 (2012). 
of dignity ${ }^{4}$ and agency, ${ }^{5}$ and, counterintuitively, make women less safe. ${ }^{6}$ Promoting a different paradigm, I argue women need security, both shortterm security that permits women to determine the best response to the domestic violence, as well as options for long-term security-economic security, housing security, health security, and relationship security-that will support their own resilience and allow them to grow, thrive, and direct their lives after experiencing intimate partner abuse.

With federal and state domestic violence funding devoted largely to law enforcement, and civil remedies emphasizing only physical violence and primarily short-term remedies, women subjected to abuse get most of our attention only in moments of crisis. Emergency measures temporarily

4. Human dignity is the capacity of persons to be decision makers using "their own conscience and conviction" regarding "the most fundamental questions touching the meaning and value of their own lives." Margaret E. Johnson, Balancing Liberty, Dignity, and Safety: The Impact of Domestic Violence Lethality Screening, 32 CARdozo L. Rev. 519, 546 (2010) [hereinafter Johnson, Balancing Liberty] (quoting Ronald Dworkin, Unenumerated Rights: Whether and How Roe Should be Overruled, 59 U. CHI. L. Rev. 381, 426 (1992)) (internal quotation marks omitted). Dignity recognizes that women subjected to abuse have the right to decide how best to address the intimate partner abuse without unwanted state intrusion or coercion. See $i d$. at 547 . For a discussion of the importance of dignity in domestic violence law and policy, see $i d$. at 519, 543-46.

5. Agency is the "'capacity for self-definition and self-direction' despite subordination based on gender." Margaret E. Johnson, Redefining Harm, Reimagining Remedies, and Reclaiming Domestic Violence Law, 42 U.C. DAvIS L. REv. 1107, 1114 n.24 (2009) [hereinafter Johnson, Redefining Harm] (quoting Kathryn Abrams, Subordination and Agency in Sexual Harassment Law, in Directions in Sexual HarassMENT Law 112-14 (Catharine A. MacKinnon \& Reva B. Siegel eds., 2004)). It is important that the domestic violence legal system and policy respect the agency of women subjected to abuse, because research shows that women are the best predictors of their risk of future abuse and are able to make decisions that best address the abuse. See id. at 1124-29.

6. To discuss domestic violence, I use the terms domestic violence and intimate partner abuse interchangeably to mean all the forms of abuse inflicted on an intimate partner in an attempt to exert power and control over her. I focus on male-on-female abuse because it is the most prevalent form of intimate partner abuse. See Johnson, Redefining Harm, supra note 5, at 1110 n.4 (citing Joan B. Kelly \& Michael P. Johnson, Differentiation Among Types of Intimate Partner Violence: Research Update and Implications for Interventions, 46 FAм. Ст. REv. 476, 481-82 (2008)). Recognizing that men can be subjected to abuse as well, I often discuss persons subjected to abuse. And finally, I use the term subjected to abuse rather than victim or survivor of domestic violence because the latter two terms may cause the essentialization of a person by her experience of domestic violence. See id. at 1112 n.13. As I discuss in this Article, domestic violence law and policy need to do a better job of accounting for the whole person, and thus, I prefer the term woman or person subjected to abuse. For the same reason, I do not call the person perpetrating the acts of abuse a batterer as the term may reduce his personhood in ways that may not resonate with the woman in relationship with him. See id. I will use the term victims when discussing how the criminal justice system views women subjected to abuse. And in discussing court cases, I use the terms designated by the court system, such as petitioner, for the person subjected to abuse, and respondent or defendant, for the person who committed the abuse. 
separate women from their partners who are abusing them, offering women a sometimes desperately-needed refuge.

But then what? Like Mary, many women who experience domestic violence find themselves homeless and jobless when the dust settles. Like Mary, they may have found temporary, emergency housing in a shelter for victims of domestic violence. They may have received crisis counseling. But then, life marches on.

Persons subjected to intimate partner abuse may have been forced from their homes because they lacked ownership rights and to avoid future abuse. They may have lost their jobs because injury or stress caused them to miss work, or because their partner locked them in the house, or because their partner's on-the-job harassment frightened a boss or coworkers. In some instances, women may lose their children to foster care, accused of "failing to protect" the children from the man who has endangered them. ${ }^{7}$ Persons subjected to abuse may have lasting physical and mental health damage from the intimate partner abuse to which they were subjected. ${ }^{8}$

Displaced from home, employment, and education; exiled from their community; and separated from their children, women who experience abuse may be safe when the most conspicuous crisis passes. Or the responses taken through physical separation may have made them less safe. Either way, are they living their fully-actualized life? Not yet.

And so the anti-domestic violence movement is at a choice moment. It is time for a change. It is time for the anti-domestic violence movement to consider taking a critical look at the state and institutional response to domestic violence and the current goal of safety, asking whether each established response or new initiative is addressing the needs of persons subjected to abuse in terms of their personal goals, resilience, agency, and dignity. The idea is for the response to be centered on the person's experience of the abuse and not centered on the state or institution. This shift is one that needs to move from a primarily short-term safety focus to a short and long-term security focus. Security would include increasing access to resources to increase economic, housing, health, and relationship security of persons subjected to abuse. Security would require that all new legislative, policy, and funding initiatives address these areas. ${ }^{9}$

7. See Justine A. Dunlap, The "Pitiless Double Abuse" of Battered Mothers, 11 Aм. U. J. Gender Soc. Pol'y \& L. 523, 525-28 (2003) (describing how New York's child welfare department found mothers neglectful of their children because mothers were subjected to domestic violence).

8. See Lisa A. Goodman \& Deborah Epstein, Listening to Battered Women: A Survivor-Centered Approach to Advocacy, Mental Health, and Justice 55-57 (2008) (discussing prevalence of posttraumatic stress disorder among persons subjected to abuse).

9. The security paradigm's requirement builds upon Donna Coker's "material resources test." See Donna Coker, Addressing Domestic Violence Through a Strategy of Economic Rights, 24 Women's RTs. L. Rep. 187, 189 (2003) [hereinafter Coker, Economic Rights]. Specifically, Coker states: 
This Article argues that the vast majority of current domestic violence law and practice is oriented almost obsessively on short-term safety. Domestic violence policy has accordingly prioritized the narratives of physical violence, crime, and danger over women's experience of the broad-range of abuse to which they are subjected, their experienced harms, and their goals for greater satisfaction, including reduction or elimination of the abuse. ${ }^{10}$

I argue that the criminal justice system has been the axis around which much current anti-domestic violence policy has been formulated. As the iconic manifestation of state power, domestic violence policy and practices have focused on crimes, physical violence, and the pursuit of the physical safety of community members. ${ }^{11}$ Examples of policies and practices focused on physical safety include laws mandating the arrest of suspected perpetrators of domestic violence and laws forbidding prosecutors from dismissing prosecutions-despite the fact that both approaches have very mixed results in decreasing violence and sometimes increase it. ${ }^{12}$ Other examples include expansive funding for these criminal justice system initiatives, thereby taking resources away from civil legal system re-

\footnotetext{
Every anti-domestic violence law, policy, funding priority, administrative rule, you name it, should be subjected to a material resources test, which asks: What is the impact, what is the effect of this law, policy, regulation, et cetera, on the material resources of the women who are likely to come in contact with this law, policy, regulation, et cetera? Will this have an impact that either primarily or secondarily gives women greater access to material resources? Because women's circumstances differ in ways that dramatically affect their access to material resources, further, I argue, the standard for determining whether or not a given law, policy, et cetera, passes muster under a material resources test should be the situation of the women who are in the greatest need, those who are dramatically affected by the inequalities of gender, race, and class.
}

Id.; see also Kameri Christy-McMullin, Designing Policies that Address the Relationship Between Woman Abuse and Economic Resources, 29 J. Soc. \& Soc. Welfare 109, 115 (2002) [hereinafter Christy-McMullin, Designing Policies] (“[M] ost authors who do suggest policy implications or changes [for women subjected to intimate partner abuse] typically focus on short-term solutions (helping women through the crisis) rather than obtaining long-term economic security. Tragically, such a narrow focus is prohibitive of effective programs and interventions being implemented. Furthermore, it can be predicted that women will find it hard to succeed within the limits of these incomplete and inadequate policies and programs . ...”).

10. In addition, as Beth Richie recently commented, the

Emerging feminist analysis [of the domestic violence movement] did not include race and class ... [as the] white women ha[d] the power to define which problems are real. And from those definitions came very narrow definitions of who is entitled to protection, ... more married you are, the more American, the more legal, the more temporarily poor, the fewer felony convictions the more you will be entitled to the attention and resources of this movement. And these very narrow definitions of the problem aligned with state interest.

Beth Richie, Keynote Address at University of Miami Law School Converge! Conference (Feb. 7, 2014) (notes from conference on file with author).

11. See infra notes 52-119 and accompanying text.

12. See id. 
sponses and grassroots organizations that provide necessary short and long-term responses to domestic violence; ${ }^{13}$ a civil legal system that prioritizes physical abuse and crimes, thereby failing to remedy the full range of abuse that society has an interest in eradicating; ${ }^{14}$ not enough funding for emergency shelters and very little funding for longer-term housing, ${ }^{15}$ despite the importance of housing in decreasing violence and stabilizing the life of a person subjected to abuse; ${ }^{16}$ and not enough funding or support responses to increase the economic, housing, health, and relationship security of persons subjected to domestic violence. ${ }^{17}$ In addition, the response has been focused on short-term assistance, such as arrests, prosecutions, incarcerations, short-term civil protection orders, and emergency shelters, aimed at the immediate safety risk with far less attention to the longer-term. ${ }^{18}$

The negative consequences of the safety paradigm include the inability of persons subjected to abuse to be heard in the legal system because they do not experience severe enough violence, ${ }^{19}$ because what they want is not deemed "safe" by the institutions and the state from which they may be seeking assistance, ${ }^{20}$ and because they have not sought assistance but are coerced or ordered to receive assistance to be "safe," as deemed by the institutions and the state. ${ }^{21}$ Being safe and free from violent harm is important. Yet there is an important difference between the woman subjected to abuse choosing to employ actions to be safe and free of violent harm and the state requiring the woman to physically separate from her abusive partner. In addition, there is an important difference between the

13. See id.; see also Coker, Economic Rights, supra note 9, at 188.

14. See Johnson, Redefining Harm, supra note 5, at 1131-38.

15. See Margaret E. Johnson, A Home with Dignity: Domestic Violence and Property Rights, 2014 BYU L. Rev. 1, 40-43 (2014) [hereinafter Johnson, Home].

16. See id. at $11-17$.

17. See infra notes 52-119 and accompanying text.

18. See Erika A. Sussman, The Civil Protection Order as a Tool for Economic Justice, Advoc. Q., 2006 Issue 3, at 1 (citing to legislative history for state civil protection order statutes and showing purpose is to promote safety).

19. See Johnson, Redefining Harm, supra note 5, at 1145-48.

20. See Laurie S. Kohn, The Justice System and Domestic Violence: Engaging the Case but Divorcing the Victim, 32 N.Y.U. Rev. L. \& Soc. Change 191, 225-34 (2008) (discussing courts' denials of petitioners' motions to vacate civil protection orders because it would not be safe); Tamara L. Kuennen, "No-Drop" Civil Protection Orders: Exploring the Bounds of Judicial Intervention in the Lives of Domestic Violence Victims, 16 UCLA Women's L.J. 39, 53 (2007) (discussing judges' denials of petitioners' motions to vacate civil protection orders).

21. See Jeannie Suk, At Home in The Law: How the Domestic Violence Revolution Is Transforming Privacy 42 (2009) (discussing state-ordered de facto divorce through no contact orders); Kimberly D. Bailey, It's Complicated: Privacy and Domestic Violence, 49 Aм. CRIM. L. Rev. 1777, 1792-94 (2013) (discussing mandatory state policies); Johnson, Balancing Liberty, supra note 4, at 570-74; G. Kristian Miccio, A House Divided: Mandatory Arrest, Domestic Violence, and the Conservatization of the Battered Women's Movement, 42 Hous. L. Rev. 237, 296-98 (2005) (discussing state coercion of women subjected to abuse through mandatory criminal justice system interventions). 
many ways that she may act in order to create safety for herself-such as having her own finances, or continuing the relationship but eradicating the abuse-and the almost one-size-fits-all way in which the state says she should act to create safety-physically separating from her partner. The state and institutions too often use physical separation reflexively in ways that are not responsive to the situation of a woman who is experiencing or has experienced abuse. As a result, a woman's own agency and dignity can be undermined in pursuit of what is deemed safe by others. The harm of this undermining may be greater than the harm that the safety measures would address. These institutional and state responses can cause significant negative consequences as shown by the research that says that women subjected to abuse are the best predictors of violence, ${ }^{22}$ that non-physical violence is more damaging to women subjected to abuse than the physical violence, ${ }^{23}$ and that the most effective response to help women subjected to abuse is personalized. A personalized response would ensure that their goals are listened to and that there are many options from which they can evaluate and choose as opposed to having decisions made for them. ${ }^{24}$

Moreover, the safety paradigm reinforces the problematic victim paradigm. ${ }^{25}$ This construction of safety is problematic for several reasons. It reinforces gender stereotypes of helpless women who stay with abusers because they cannot think rationally and take actions to protect themselves. ${ }^{26}$ The safety paradigm also constructs women's worlds as being

22. See Johnson, Balancing Liberty, supra note 4, at 558-60.

23. See Johnson, Redefining Harm, supra note 5, at 1113 n.20 (stating that women identified "threats and verbal abuse as more devastating than the physical" (quoting Elizabeth M. Schneider, Battered Women \& Feminist Lawmaking 66 (2000)) (internal quotation marks omitted)).

24. See Donna Coker, Shifting Power for Battered Women: Law, Material Resources, and Poor Women of Color, 33 U.C. DAvis L. Rev. 1009, 1017-20 (2000) [hereinafter Coker, Shifting Power] ("It is a cruel trap when the state's legal interventions rest on the presumption that women who are 'serious' about ending domestic violence will leave their partner while, at the same time, reducing dramatically the availability of public assistance that makes leaving somewhat possible. . . The second problem with equating separation with safety is that legal actors frequently believe a corollary presumption: women's use and full cooperation with legal remedies increases their safety. ... The third problem with equating separation with safety is that frequently the laws and services based on a separation premise devalue women's connections with their partner and their investment in building family." (footnotes omitted)); Johnson, Balancing Liberty, supra note 4, at 578-80.

25. See Nadine Strossen, A Feminist Critique of "The" Feminist Critique of Pornography, 79 VA. L. REv. 1099, 1151-52 (1993).

26. One reason offered for this framing is that it is rooted in Dr. Lenore Walker's work on learned helplessness and battered women's syndrome, that women subjected to abuse are coerced into passivity and non-action. See Leigh Goodmark, A Troubled Marriage: Domestic Violence and the Legal System 57-61 (2013); Kohn, supra note 20, at 206-09. Another reason, I argue, is that this construction of women as victims is much broader than originating in domestic violence theory and is rooted in gender oppression writ large. For instance, such a construction of women as victims is seen in such early writings as Blackstone's commentaries discussing coverture and women's necessary loss of legal identity upon marriage. See 1 William Blackstone, Commentaries *430 ("By marriage, the hus- 
filled with dangers and havens-the dangers are identified and removed by the state or institutions, while the havens are identified and provided by the state or institutions. Because the state and institutions construct the "danger" as physical violence, laws and funding streams prioritize this danger as the "problem." This leaves fewer resources for the broader range of intimate partner abuse. Relying on the safety construct, lawmakers funnel a large percentage of public funds into the criminal justice system in response to domestic violence. ${ }^{27}$ The preference for criminal justice measures contributes to long-standing systemic issues plaguing persons subjected to intimate abuse. The issue is illustrated in the housing context where, even though domestic violence is the leading cause of family homelessness, a relatively small percentage of public funds is spent on housing for persons subjected to abuse. ${ }^{28}$ Despite research that shows women are best able to predict their own risk, the state and institutions construct a "haven" based on their view of the problem, thereby prioritizing their ideas of how best to save women from the violence, while not prioritizing women's own perception of what is "safe" for themselves today, tomorrow, and in the future. As a result, the state and institution construction of danger and havens does not always effectuate even short-term safety because it misdiagnoses the problem and generates inappropriate options. The state and institutional construction of safety deters the creation of laws and funding that support women's security-their resiliency, agency, and dignity-over the long-term, not just in the short-term.

This Article argues that the safety paradigm misses the forest for the trees. Arguing for a reorientation toward "security," this Article suggests that the current "safety paradigm" is harmful to women and fails even to achieve its stated objective of ensuring women's safety. A broadened, realistic vision of women's strengths and needs can provide women with the support, tools, and resources needed to fully repair their lives from the harm inflicted in abusive relationships. Measures designed to promote security recognize women's interests in sustained growth, health, and agency. Reorienting societal responses toward ensuring women's health, housing, and economic viability can provide the stability women need to make choices consistent with their own definitions of dignity and selfworth while, not coincidentally, keeping them safer in the long run. The reframing of the domestic violence movement from the predominant goal of safety to security will help reshape a legal system that can be more re-

band and wife are one person in law: that is, the very being or legal existence of the woman is suspended during the marriage, or at least is incorporated and consolidated into that of the husband: under whose wing, protection and cover she performs every thing ....").

27. See infra notes 52-119 and accompanying text.

28. See Facts on Homelessness, Housing, E् Violence Against Women, NAT'L L. CTR. on Homelessness \& Poverty, available at http://www.nlchp.org/documents/DV_ Fact_Sheet. 
sponsive to the needs and harms of persons subjected to abuse, such as Mary, while also addressing domestic violence more effectively.

This Article proceeds in three parts. Part II examines the prevailing short-term safety paradigm goal of anti-domestic violence legal and funding systems. This Part also analyzes the different policies and laws used to effectuate the safety paradigm, such as the criminal justice system itself, mandatory arrest and prosecution policies, mandatory no contact orders, civil protection orders (CPO) mandating physical separation, domestic violence shelter mandated separation, lethality assessment programs, and the lack of robust long-term options for housing, employment, and financial stability. This Part concludes by discussing how these policies affect women subjected to abuse as well the epidemic of domestic violence generally.

In Part III, I propose that security, not safety, serve as the philosophical driving force behind domestic violence law and practice. I argue that law, funding, policy, and practice should promote long-term assistance intended to support resilience, agency, and dignity. Such a response would include long-term housing options, including the ability to be within a supportive community; long-term employment or other income-generation options, with long-term employment supports such as career counseling, education, quality child care, and available transportation; increased income and asset-building opportunities without the barriers of discrimination; access to public assistance; long-term physical and mental health care, preventative, and treatment options; long-term civil protective and other court orders that provide injunctive, family, housing, and economic remedies; and the development of enhanced social capital and community connection for persons subjected to abuse. An approach oriented toward long-term measures, such as these, would provide the security and stability women need to determine how best to address the violence in their relationships.

Finally, in Part IV, I offer examples of how the domestic violence legal and funding systems could do more to address security. For example, the legal and funding systems could address all forms of intimate partner abuse, end mandatory responses to domestic violence, address barriers to employment and access to secure and livable wages, address coerced debt, expand opportunities for asset building, increase housing options, support social capital development through time banking, and provide monetary damages for domestic violence.

\section{Domestic Violence: SAfety Paradigm}

To understand the prevailing safety paradigm, it is important to understand what domestic violence is and how our current laws and policies address domestic violence. 


\section{A. Domestic Violence}

Research has demonstrated that domestic violence, or "intimate partner abuse," can take a wide range of forms, in addition to physical aggression by one partner against another. According to social work professor Judy Postmus, for example, intimate partner violence is:

[A] pattern of behavior in a relationship by which the batterer attempts to control his victim through a variety of tactics. These tactics may include fear and intimidation, physical and/or sexual abuse, psychological and emotional abuse, destruction of property and pets, isolation and imprisonment, economic abuse, and rigid expectations of sex roles. ${ }^{29}$

This pattern of behavior has been called "[c]oercive [c]ontrolling [v]iolence" 30 or "coercive control." 11 Such abuse may involve one of these tactics alone, such as physical abuse, or employ several or all tactics. ${ }^{32}$ As psychologists Mary Ann Dutton and Lisa Goodman have documented in their studies, there are nine areas of coercive control used by abusers on their partners: "personal activities/appearance," "support/social life/family," "household," "work/economic/resources," "health," "intimate relationship," "legal," "immigration," and "children."33 Of the various forms of domestic violence, women subjected to intimate partner abuse "frequently describe the threats and verbal abuse as more devastating than the physical." 34 Further, research shows that psychological abuse often can develop into physical abuse. ${ }^{35}$

Focusing on economic abuse, law professor Dana Harrington Conner catalogues three forms: (1) targeting women of limited economic means, in poverty, in vulnerable situations because of immigration status, limited English proficiency, connection to their community, or limited social capital; (2) creating financial dependence by precluding access to money and

29. Judy L. Postmus, Analysis of the Family Violence Option: A Strengths Perspective, 15 AfFilia 244, 244-45 (2000) (citations omitted).

30. Kelly \& Johnson, supra note 6 , at 481.

31. Evan Stark, Coercive Control: The Entrapment of Women in PerSONAL LIFE 12-13 (2007).

32. See Kelly \& Johnson, supra note 6, at 481 ("Abusers do not necessarily use all of these tactics, but they do use a combination of the ones that they feel are most likely to work for them. Because these nonviolent control tactics may be effective without the use of violence (especially if there has been a history of violence in the past), Coercive Controlling Violence does not necessarily manifest itself in high levels of violence.").

33. Mary Ann Dutton \& Lisa A. Goodman, Coercion in Intimate Partner Violence: Toward a New Conceptualization, 52 Sex Roles 743, 747 (2005).

34. Elizabeth M. Schneider, Battered Women and Feminist Lawmaking 66 (2000); see also Eve Schlesinger Buzawa \& Carl G. Buzawa, Domestic Violence: The Criminal Justice System Response 25 (3d ed. 2002); Lenore E. Walker, The BATtered Woman 34 (2d ed. 2000).

35. See Johnson, Redefining Harm, supra note 5, at 1113 (citing Kelly \& Johnson, supra note 6 , at 483 ). 
property resources, sabotaging one's economic stability and property ownership, precluding or sabotaging employment and education opportunities, and/or isolating from people; and (3) limiting access to economic resources, destroying whatever economic resources she may have, and damaging social capital. ${ }^{36}$ The coercion around work and finances is a significant form of intimate partner abuse because it is so powerful. Such coercion can include " $[\mathrm{m}]$ aking or attempting to make a person financially dependent, e.g., maintaining total control over financial resources, withholding access to money, forbidding attendance at school or employment." 37 Further tactics include acts such as "sabotag[ing] a woman's efforts to find a job or attend a job training ... . [by] turning off her alarm clock so she will be late for work, cutting off her hair to cause her great embarrassment, inflicting visible injuries or creating conflicts before crucial events, and hiding or destroying her books, homework, or clothing." 38 Even if the woman becomes successfully employed, the abuse may continue with the intimate partner "disrupting her transportation or childcare arrangements or harassing her at work." 39

As discussed above, domestic violence can be perpetrated in multiple ways, with varying tactics to exert coercive control, beyond simply physical violence.

\section{B. The Safety Paradigm}

The current safety paradigm of anti-domestic violence law and policy is the result of responses to the state's initial absence of a response to domestic violence. Domestic violence advocacy in the 1960s was a grassroots movement, focused on all forms of abuse, and on women's empowerment, agency, and dignity as a way to address the abuse. ${ }^{40}$ Women who experienced abuse were provided counseling focused primarily on consciousness-raising about domestic violence as a form of gender oppression. ${ }^{41}$ Most of the efforts were expended to create a network of grassroots shelters to which women could escape from abusive relationships. ${ }^{42}$

In the 1970 s and 1980s, feminists focused on the void of state responses to the continued epidemic levels of abuse and lobbied the state

36. See Dana Harrington Conner, Financial Freedom: Women, Money, and Domestic Abuse, 20 WM. \& MarY J. Women \& L. 339, 357-69 (2014).

37. Johnson, Redefining Harm, supra note 5, at 1120 (alteration in original) (quoting What is Domestic Violence?, WoMEnsLaw.org, http://www.womenslaw.org/ simple.php?sitemap_id=39) (internal quotation marks omitted).

38. Postmus, supra note 29, at 246.

39. $I d$.

40. See Kohn, supra note 20, at 196 (stating that general social activism of 1960 s included activism against women's subordination in society, including through domestic violence).

41. See Susan Schechter, Women and Male Violence: The Visions and Struggles of the Battered Women's Movement 62-68 (1982).

42. See Kohn, supra note 20, at 196. 
for formal laws and policies to address intimate partner violence. ${ }^{43}$ That lobbying focused on domestic violence as physical violence and especially criminal acts. ${ }^{44}$ Finding that the state's response was nonetheless still often lacking, advocates successfully lobbied for new laws to remove state actors' discretion by mandating the arrest and prosecution of suspected batterers. ${ }^{45}$ States enacted civil protection order laws, permitting women to seek protection primarily from physical abuse that would constitute a crime regardless of the outcome of criminal proceedings against a batterer. $^{46}$ Through this engagement of the state, philosophical and funding priorities changed from women's own empowerment responses addressing broad forms of intimate partner abuse to the state and other outsiders' responses addressing primarily criminal physical abuse. In 1994, the Violence Against Women $\mathrm{Act}^{47}$ (VAWA) was enacted, and 1.6 billion dollars ${ }^{48}$ were allocated to support legal, court, and community-based responses to domestic violence, which were focused on combatting physical violence and used short-term physical separation as the remedy. ${ }^{49}$

As a result of these efforts, there are police who will now arrest persons for abusing their partner, there are prosecutors who will finally prosecute these crimes, there are civil protection order laws, and there is a developed coordinated response of criminal and civil courts dedicated to domestic violence. ${ }^{50}$ There are also many services developed to respond to domestic violence, including civil legal services for civil protective orders, emergency shelters, counseling, transitional housing, and more. ${ }^{51}$

43. See id. at 196-97.

44. Cf. Buzawa \& Buzawa, supra note 34, at 4-5 (“[C]riminal justice case processing requirements may have directly defined the parameters of permissible contact by criminalizing certain violent conduct, while tacitly condoning harassment or other strategies of coercive control, actions that in practice rarely result in arrest or prosecution.").

45. See Kohn, supra note 20, at 196-97, 199; Miccio, supra note 21, at 278.

46. See Kohn, supra note 20, at 196-97.

47. Violence Against Women Act of 1994, Pub. L. No. 103-322, $\S \S$ 40001-40703, 108 Stat. 1902.

48. See Robert F. Friedman, Note, Protecting Victims from Themselves, but Not Necessarily from Abusers: Issuing a No-Contact Order over the Objection of the Victim-Spouse, 19 WM. \& Mary Bill RTs. J. 235, 239 (2010) (citing Julie Goldscheid, United States v. Morrison and the Civil Rights Remedy of the Violence Against Women Act: A Civil Rights Law Struck Down in the Name of Federalism, 86 Cornell L. Rev. 109, 113 (2000)).

49. See Kohn, supra note 20, at 200 ("Most individuals in the justice system hope to protect battered women from further violence by seeking to remove them from abusive relationships."). VAWA also contained a civil rights provision for persons subjected to abuse that permitted them to get injunctive and declaratory relief as well as compensatory and punitive damages for crimes of violence motivated by gender. See Goldscheid, supra, at 113-15. This provision was later struck down by the Supreme Court as unconstitutional. See United States v. Morrison, 529 U.S. $598(2000)$.

50. See generally Deborah Epstein, Effective Intervention in Domestic Violence Cases: Rethinking the Roles of Prosecutors, Judges, and the Court System, 11 YAle J.L. \& FEMInism 3 (1999).

51. See Goodmark, supra note 26, at 25-28. 
These developments have occurred in large part due to the success of the anti-domestic violence movement and its alliance with the state, including the large amounts of government funding that support the governmentdesigned response and, to a much lesser extent, the non-legal response. Many of these developments constitute the safety paradigm.

\section{The Safety Paradigm in Contemporary Law, Policy, and Practice}

The safety paradigm has four components. First, it is focused on primarily physical and sexual violence as domestic violence rather than also looking at psychological, emotional, and economic abuse and coercive control. ${ }^{52}$ Second, its goal is principally to address the immediate crisis and defuse the situation through short-term remedies. Third, its goal is to ensure that the government ends future physical and sexual violence through the physical separation of the parties. ${ }^{53}$ Fourth, it provides that the state, and not the person subjected to abuse, is the decision maker as to how best to address the domestic violence. ${ }^{54}$ There are many examples of the safety paradigm in the current domestic violence law and funding schemes.

The criminal justice system demonstrates a safety paradigm as it is generally only concerned with physical violence, injuries caused by physical violence, and remedies ensuring physical separation through arrest, criminal prosecution, incarceration, fines, criminal stay away orders, and batterers intervention programs. ${ }^{55}$ Moreover, the state is the decision maker as to the remedy pursued and not the person subjected to abuse. ${ }^{56}$

52. See Buzawa \& Buzawa, supra note 34 , at 4-5 ("[C] riminal codes are typically rather blunt instruments, defining violence as individual acts, usually a physical assault or threat of physical harm intended to cause physical harm.").

53. See id. at 5 (explaining criminal justice system has "implicit requirement for the identification of a crime with a defined victim and offender in the context of a recognized applicable criminal statute"); JENNIFER G. LONG ET AL., AEQUiTAS, Model Policy for Prosecutors and Judges on Imposing, Modifying and Lifting Criminal No Contact Orders 2 (2010), available at http://www.aequitasresource .org/model_policy.pdf (stating that goals of criminal justice system regarding domestic violence are "to seek justice, protect the victim and the community, hold the offender accountable for his crimes, prevent and deter future crime, and rehabilitate the abuser").

54. See Buzawa \& Buzawa, supra note 34 , at 4 (discussing ascendancy of criminal justice system domestic violence response: "the United States currently has a propensity to use coercive legal powers to 'solve' social problems").

55. It should be noted that prosecutors' offices do staff victim advocates who work with the persons subjected to abuse and address some short-term needs such as housing and food. Primarily, these victim advocates are in place to help obtain the cooperation of the person who was subjected to abuse in the prosecution of the abuse. In other words, these services are offered to fulfill the criminal justice system's goals and not any incompatible goals of the person subjected to abuse. See generally Thomas L. Kirsch II, Problems in Domestic Violence: Should Victims Be Forced to Participate in the Prosecution of Their Abusers?, 7 WM. \& Mary J. WOMEn \& L. 383, 398-406 (2001); Kohn, supra note 20.

56. See Buzawa \& Buzawa, supra note 34 , at 4, 126-28. 
One clear example of this point is the mandatory arrest laws. As of December 2011, twenty-two states plus Washington, D.C. had mandatory arrest laws that required the responding police officer to arrest at least the primary aggressor if an assault had occurred. ${ }^{57}$ This requirement exists even if the person subjected to abuse opposes or does not request the arrest. In addition, thirty-three states had mandatory arrest laws that required a police officer to arrest a respondent who violated a civil protection order. ${ }^{58}$ Six states preferred arrest laws "encouraging" police officers to make arrests if an assault occurred. ${ }^{59}$ Such laws permit police officers discretion in deciding whether to arrest, including some consideration of the crime victim's opinion on the arrest. ${ }^{60}$

"No-drop" prosecution policies provide another example of the state acting as the sole decision maker as to the remedy pursued. ${ }^{61}$ Many states have developed mandatory prosecution, or no-drop prosecution policies, as a response to the early outcry by domestic violence advocates that the state was not seriously addressing domestic violence. ${ }^{62}$ In addition to the police's failure to arrest for domestic violence, advocates cited the prosecutors' failure to proceed with prosecutions of those who were in fact arrested. No-drop prosecution policies may be contained in legislation or issued by state attorney general offices and are encouraged and financially supported by federal law. ${ }^{63}$ Under "hard" no-drop policies, neither prosecutors nor the person subjected to abuse have any discretion as to whether a case supported by evidence will go forward. Prosecutors must prosecute the case even when the crime victim, the person subjected to abuse, requests that the case be dismissed and/or refuses to cooperate with the prosecutor by being interviewed or testifying at trial. ${ }^{64}$ "Soft" no-drop prosecution policies permit prosecutors to dismiss criminal cases based on

57. See Univ. of Ky. Ctr. for Research on Violence Against Women, ReSearch to Practice Brief 2 (Dec. 2011), available at https://opsvaw.as.uky.edu/ sites/default/files/05_Mandatory_Arrest.pdf.

58. See id.

59. See id.

60. See Amy M. Zelcer, Note, Battling Domestic Violence: Replacing Mandatory Arrest Laws with a Trifecta of Preferential Arrest, Officer Education, and Batterer Treatment Programs, 51 Аm. Crim. L. Rev. 541, 554-55 (2014).

61. See Cheryl Hanna, No Right to Choose: Mandated Victim Participation in Domestic Violence Prosecutions, 109 Harv. L. Rev. 1849, 1853 (1996).

62. See Buzawa \& Buzawa, supra note 34, at 194-95 ("[Sixty-six percent] of a sample of local prosecutors in jurisdictions with populations of over 250,000 had no-drop policies."); see also Miccio, supra note 21, at 265.

63. See Angela Corsilles, Note, No-Drop Policies in the Prosecution of Domestic Violence Cases: Guarantee to Action or Dangerous Solution?, 63 Fordham L. Rev. 853, 863-65 (1994) (citing state legislation, state attorney generals' policies, and the Federal Child Abuse, Domestic Violence, Adoption and Family Services Act of 1992). Specifically, Corsilles discusses section 10415 of the Act, which provides state grants for their no-drop prosecution policies. See id. at 864; see also Federal Child Abuse, Domestic Violence, Adoption and Family Services Act of 1992, Pub. L. No. 102-295, 106 Stat. 187.

64. See Miccio, supra note 21, at 266. 
the victim's desires if the victim has physically separated from the defendant. ${ }^{65}$ One stated justification for a hard no-drop policy is victim safety. Such safety is intended to result from the prosecution and eventual incarceration, criminal stay away orders, or rehabilitation training of defendants that will in turn reduce future battering through separation, stigmatizing the relationship, and notifying the victim and defendant that the victim cannot be controlled by the defendant. Moreover, the no-drop policy informs victims who desire to stay with the defendant that their wishes are the result of coercion and not agency. ${ }^{66}$

Criminal no contact orders are another example of the safety paradigm. Criminal no contact orders are instituted almost routinely during the prosecution of a domestic violence crime as part of pretrial release and are often included as part of the sentence. ${ }^{67}$ These stay away orders are ordered even against the will of the person subjected to abuse. ${ }^{68}$

Civil protection order laws permit persons subjected to abuse to petition a civil court for various forms of injunctive relief, such as no further abuse, stay away, no contact, and vacate the home orders; family-based relief, such as a temporary child custody and support order; and other relief, such as domestic violence counseling and control over some forms of personal property. ${ }^{69}$ All United States jurisdictions permit a petition for a protective order to be based upon a criminal or violent act between intimate cohabitating partners. ${ }^{70}$ CPOs contain both safety and security elements, but the predominant elements are the safety elements. Only one-third of all jurisdictions recognize or remedy harms from emotional and economic abuse, and only one-third of the jurisdictions recognize and provide a remedy for coercive control. ${ }^{71}$ Further, only thirty-seven CPO laws provide a catch-all provision that could provide an economic remedy beyond child or spousal support to include compensatory and punitive damages. ${ }^{72}$ On the other hand, all CPOs contain directives specifically based on the physical separation safety paradigm and last for a short time, usually one year in length. ${ }^{73}$ In some jurisdictions, the petitioners' choice

65. See Friedman, supra note 48 , at 242 (citing Buzawa \& Buzawa, supra note 34 , at 194).

66. See id. at 242-43.

67. See Buzawa \& Buzawa, supra note 34 , at 235; Friedman, supra note 48 , at $246-47$.

68. See Friedman, supra note 48 , at 247.

69. See Johnson, Redefining Harm, supra note 5, at 1131; Catherine F. Klein \& Leslye E. Orloff, Providing Legal Protection for Battered Women: An Analysis of State Statutes and Case Law, 21 Hofstra L. Rev. 801, 910-1031 (1993).

70. See Johnson, Redefining Harm, supra note 5, at 1131-32; Klein \& Orloff, supra note 69 , at $848-58$.

71. See Johnson, Redefining Harm, supra note 5, at 1133-38.

72. New Jersey has provided compensatory and punitive damages under its catch-all provision. See Klein \& Orloff, supra note 69, at 912 n.695.

73. Jurisdictions vary on the duration of CPOs: three months (two states); six months (five states); one year (twenty-two states); eighteen months to two years (nine states); three to five years (eight states); and a few with permanent protective 
of how best to address the abuse is severely limited, in that she may not request an injunction against further abuse without also requesting a stay away and no contact order. ${ }^{74}$ Even when the governing statute does not mandate physical separation, courts deciding CPO matters have required it even against the will of the petitioner, the person subjected to abuse requesting the CPO. In certain jurisdictions, if the petitioner chooses to vacate her CPO after it is issued, the court will not permit her to do so. ${ }^{75}$ One court in New Jersey stated that it would not vacate the order because its duty was to protect the victim of domestic violence. ${ }^{76}$ The cycle of violence theory-that is related to battered women's syndrome-states that after violent incidents, the abusive partner apologizes and creates a "honeymoon"-like atmosphere in the relationship, thus, the women subjected to abuse are lulled into a false sense of security that the violence is over. ${ }^{77}$ Courts refusing to vacate CPOs override women's wishes, relying on the cycle of violence to justify the courts' decisions. ${ }^{78}$ This reliance exists despite the fact that researchers have questioned the theory's validity and universal applicability. ${ }^{79}$

Similarly, crime victim compensation fund laws may discourage payment to a person subjected to abuse if she has not physically separated from or continues to reside with the person who committed the abuse. For instance, under West Virginia law, no payment of monies may be made to a person subjected to abuse who chooses to maintain her home with her partner who was abusive because the monies should not serve to support the offender or cause him unjust enrichment. ${ }^{80}$ Accordingly, the person subjected to abuse who chooses to maintain her relationship with the person who had abused her could be denied funds to support her housing and daily living expenses that she would otherwise be able to collect if she were physically separated from her partner.

Domestic violence shelters also illustrate aspects of the safety paradigm. First, many shelters make decisions for residents as to how they spend their time in the shelter and require certain behaviors to gain access to the shelter. For instance, many shelters require residents to undergo

orders. See Jane K. Stoever, Enjoining Abuse: The Case for Indefinite Domestic Violence Protection Orders, 67 VAnd. L. Rev. 1015, 1046-50 (2014).

74. See Johnson, Home, supra note 15, at 45 n.198 (citing Sally F. Goldfarb, Reconceiving Civil Protection Orders for Domestic Violence: Can Law Help End the Abuse Without Ending the Relationship?, 29 CARdozo L. Rev. 1487, 1504 n.110 (2008)) (discussing N.J. Stat. Ann. § 2C:25-28.1, which establishes that no protection order can be granted that would permit respondent to share premises with petitioner). See generally Jane K. Stoever, Freedom from Violence: Using the Stages of Change Model to Realize the Promise of Civil Protection Orders, 72 Онго Sт. L.J. 303, 333 (2011).

75. See Kohn, supra note 20, at 225-26; Kuennen, supra note 20, at 45-46. 1998).

76. See Stevenson v. Stevenson, 714 A.2d 986, 992 (N.J. Super. Ct. Ch. Div.

77. See Goodmark, supra note 26 , at $31-33$.

78. See id. at 33.

79. See id. at 32-33.

80. See W. VA. Code Ann. $§ 14-2 A-26$ (West 2012). 
therapy and substance abuse counseling, abide by bureaucratic rules, apply for public benefits, and conform their parenting to certain guidelines as a condition of remaining in the shelter. ${ }^{81}$ These requirements are dictated in large part by the funding they receive. Second, many domestic violence shelters require separation by locating in confidential locations to prevent women's partners from being able to find them. ${ }^{82}$ Many shelters also require that the woman subjected to abuse cease all contact with the partner who had been abusive. ${ }^{83}$ Third, most shelters exclude men or transgendered women, especially those who are not postoperative, on the assumption that men and transgendered women are potential perpetrators of abuse. ${ }^{84}$

Many of the programs described above are funded by the Violence Against Women Act and other federal laws. The largest category of federal appropriations to combat domestic violence was granted to the criminal justice system. A large category of these criminal justice system funds go towards arrest and prosecution policies, such as mandatory arrest and no drop prosecution policies. ${ }^{85}$ The federal government allocated a total of $\$ 944$ million to the criminal justice system response to domestic violence, including the Services, Training, Officers, Prosecutors (STOP) program, the Arrest Policies Program, and VOCA grant programs. ${ }^{86}$ The 2012 funding for the STOP grants was $\$ 189$ million. ${ }^{87}$ The funding is used to establish protocols and special units in prosecutors' offices and law enforcement agencies. The Grants to Encourage Arrests (Arrests Policies Program) was granted $\$ 50$ million in $2012 .{ }^{88}$ These grants are given to support "criminal justice policies, practices and procedures regarding arrest and protection order laws to enhance victim safety and ensure offender accountability." 89 A significant amount of the federal appropriations go to crime victims funds that provide financial assistance to persons subjected to physical domestic violence or other domestic violence crimes. The Victims of Crime Act Fund received $\$ 705$ million in 2012. ${ }^{90}$ While the funds may reimburse a person subjected to abuse for

81. See Johnson, Home, supra note 15 , at 44 .

82. See id. at 38 (citing Goodman \& Epstein, supra note 8, at 102).

83. See id. at 44 .

84. See Leigh Goodmark, Transgender People, Intimate Partner Abuse, and the Legal System, 48 Harv. C.R.-C.L. L. REv. 51, 67-71 (2013). See generally Melody M. Crick, Comment, Access Denied: The Problem of Abused Men in Washington, 27 Seattle U. L. REV. 1035 (2004).

85. See Richard D. Friedman \& Bridget McCormack, Dial-In Testimony, 150 U. PA. L. Rev. 1171, 1188 (2002) (noting VAWA funding supports no-drop policies).

86. See Campaign for Funding to End Domestic Violence \& Sexual AsSAUlt, FY 2013 Appropriations Briefing Book 8, 18, 39 (Mar. 2012) [hereinafter 2013 Appropriations Briefing Book], available at http://nnedv.org/downloads/ Policy/FY_13_Briefing_Book.pdf.

87. See id. at 8 .

88. See id. at 18.

89. Id.

90. See id. at 39. 
certain types of relief necessary because of the domestic violence-such as physical and mental health treatment-a person who is subjected to solely psychological, emotional, or economic abuse would not qualify because a potential recipient needs to prove that she was subjected to a crime. ${ }^{91}$

Certain short-term responses to domestic violence are also funded at a high level. The federal government allocated $\$ 173.7$ million to predominately short-term safety and security initiatives. ${ }^{92}$ Under the Family Violence Prevention and Services Act, the federal government appropriated $\$ 129.5$ million in 2012 for domestic violence shelters, counseling, and hotline services. ${ }^{93}$ The federal government granted $\$ 3.2$ million for the National Domestic Violence Hotline in 2012.94 It granted $\$ 41$ million in civil legal assistance, which covered short and long-term responses to domestic violence. ${ }^{95}$ If these short-term services were provided to effectuate goals that were not those of the person subjected to abuse, they would qualify as safety paradigm services under this Article's working definition of safety.

The federal government appropriated much less money, \$31.4 million, for long-term solutions to domestic violence. The following are the monies spent for such security items as economic, housing, health, and relationship security. For instance, in 2012, the federal government granted $\$ 25$ million in transitional housing monies. ${ }^{96}$ The Transitional Housing Assistance Grants provide monies to persons subjected to abuse for longer-term housing costs, including rent and utilities, as well as other support services, like transportation and childcare; and the grants provide monies to service providers managing the transitional housing programs. ${ }^{97}$ The government also appropriated $\$ 5.4$ million in grants to the Domestic Violence Prevention Enhancement and Leadership Through Alliances (DELTA) program. ${ }^{98}$ DELTA "supports statewide projects to integrate primary prevention principles and practices into local coordinated community responses that address and reduce the incidence of intimate partner violence," such as peer education for men about families and relationships. ${ }^{99}$ The federal government granted $\$ 1$ million in 2012 for the National Resources Center on Workplace Responses to Assist Victims of Domestic and Sexual Violence. ${ }^{100}$

91. See Jeffrey A. Parness et al., Monetary Recoveries for State Crime Victims, 58 Clev. St. L. Rev. 819, 842-50 (2010).

92. See 2013 Appropriations Briefing Book, supra note 86, at 18, 29, 31.

93. See id. at 29.

94. See id. at 32 .

95. See id. at 19 .

96. See id. at 20.

97. See id.

98. See id. at 36 .

99. Id.

100. See id. at 26. 
The safety paradigm is equally prominent in state legislation. ${ }^{101}$ In the 2012 legislative sessions, the fifty states and the District of Columbia passed 249 laws regarding domestic violence. Twenty-six states passed a total of ninety-seven criminal laws regarding domestic violence that reinforced the safety paradigm. ${ }^{102}$ Nineteen jurisdictions passed thirty-nine family law provisions regarding custody and child welfare issues that addressed both the safety paradigm as well as relationship security. Eighteen jurisdictions passed thirty-eight laws instituting procedures for orders of protection, which blended features of the safety and security paradigms, and addressed issues such as confidentiality, procedure, firearm removal, and actionable abuse. Finally, three jurisdictions passed four laws addressing treatment of offenders, exhibiting elements both of the safety and relationship security paradigms. ${ }^{103}$ Only thirteen jurisdictions addressed purely security issues, such as programs and policies relating to teen dating violence, ${ }^{104}$ unemployment insurance for persons subjected to abuse, ${ }^{105}$ in-state tuition and education waivers for persons subjected to abuse and their children, ${ }^{106}$ expanded housing options, ${ }^{107}$ expanding access to crime victims compensation fund monies, ${ }^{108}$ confidentiality protection, ${ }^{109}$ and studies examining the treatment and prevention of domestic

101. For instance, the National Council of Juvenile and Family Court Judges stated that "the 2012 legislative session [across all states] reflects steadfast focus on enhanced victim safety, increased perpetrator accountability, and ambitious prevention efforts." See Nat'l Council of Juvenile \& Family Court Judges, Family Violence: Legislative Update 4, available at http://www.ncjfcj.org/sites/default/ files/legislative_update_18.pdf (emphasis added).

102. See id. at 10-17 (tallying numbers of states that have enacted domestic violence legislation).

103. See id. at 10-13 (showing Florida, Kansas, and West Virginia have passed "prevention and treatment" legislation in addition to criminal measures).

104. See id. at 14-17 (noting Connecticut, Delaware, Illinois, and Oregon passed "adolescent partner violence" legislation).

105. See id. at 59-60. In Maryland, new legislation permits a person subjected to abuse to receive unemployment insurance if she has left her job because of the abuse. See id.

106. See id. at 26, 72 (discussing legislation in California and New Jersey). In California, legislation exempted persons subjected to abuse from paying nonresidential tuition at state universities and community colleges, permitted them to apply for financial aid, and waived community college fees. See id. at 26 . In New Jersey, new legislation requires the state to pay for any school tuition inured because a child is in a domestic violence shelter or transitional housing. See id. at 72.

107. See id. at 26, 40 (discussing amendments in California and Florida). In California, new legislation permits persons subjected to abuse to use CPOs as evidence of domestic violence to terminate a tenancy due to the abuse. See id. at 26. In Florida, legislation was passed providing relocation assistance for victims of sexual battery. See id. at 40.

108. See id. at 44. In Illinois, a new law permits a person subjected to stalking and who obtained a no stalking order to receive crime victims' compensation funding. See id. This new law is notable because it does not require the person to be subjected to physical violence.

109. See id. at 15-17 (showing ten states passed confidentiality laws in 2012). For example, in New York, health insurers must honor requests by persons sub- 
violence. Of the twenty-two pieces, only one piece of legislation, Oregon's legislation regarding teen dating violence programs, actually provides money to implement the programs. Three other laws, those dealing with in-state tuition, waiver of tuition, and access to crime victims compensation fund monies, provide access to resources or lower the cost of the resources. Accordingly, as seen above, the safety paradigm is the prominent paradigm for legislation as well as funding of domestic violence responses.

One final nationwide program that exemplifies the safety paradigm is the use of the lethality assessment screening program to evaluate women's risk of being killed because of domestic violence. ${ }^{110}$ Law enforcement officers use this program when they respond to 911 calls involving intimate partner abuse. ${ }^{111}$ It is an eleven question instrument that is administered by the officer and is designed to elicit responses by the woman. ${ }^{112}$ After answering all of the questions, the police officer scores the woman's risk of lethality, and if high, contacts a hotline or shelter, recommending that the woman speak to a counselor. ${ }^{113}$ Law enforcement officials do not give the woman being screened a choice regarding whether to be screened or to receive her score. ${ }^{114}$ If she is reluctant to speak to the counselor, law enforcement protocol instructs them to continue to persuade her to talk to the counselor. ${ }^{115}$ In addition to law enforcement, the program is being implemented by court clerks, judges, legal service providers, shelter providers, and other system actors to evaluate the severity of abuse and to determine the level of services that should be provided to the woman. ${ }^{116}$ Importantly, the screening tool has yet to be validated. ${ }^{117}$ The program started in Maryland and has been implemented in other jurisdictions. ${ }^{118}$ As of 2013, thirty jurisdictions are using the program. ${ }^{119}$

jected to abuse who want their health communications to be sent to a different address. See id. at 74. In Tennessee, new legislation exempts hospitals from having to report injuries from intimate partner abuse to law enforcement. See id. at 84 .

110. See generally Johnson, Balancing Liberty, supra note 4.

111. See id. at 532-42.

112. See id. at 533, $535 \mathrm{n} .73$ (discussing questions and listing questions asked).

113. See id. at 536-37 (noting that, although police officers should only suggest counselor at first, they are instructed to eventually "coerce" victim into compliance).

114. See id. (discussing mandatory nature of protocol).

115. See id.

116. See id. at 539-42.

117. See id. at 558. Researchers are currently studying the effectiveness of the lethality assessment screen in Oklahoma. See, e.g., Jill T. Messing et al., Collaborating with Police Departments: Recruitment in the Oklahoma Lethality Assessment (OK-LA) Study, 17 Violence Against Women 163 (2011).

118. See Johnson, Balancing Liberty, supra note 4, at 539-40; see also LAP: Nationally, Mo. Network Against Domestic Violence, http://mnadv.org/lethality/ lap-nationally/. The creators of the Lethality Assessment Program offer training and technical assistance pursuant to a cooperative agreement with the U.S. Office on Violence Against Women.

119. See LAP: Nationally, supra note 118 (noting Alabama, Arizona, California, Colorado, Connecticut, Delaware, Florida, Georgia, Indiana, Kentucky, Maryland, 


\section{Evaluation of the Safety Paradigm}

There is good reason to be concerned about the safety of persons subjected to abuse. Deprivations of liberty and dignity by assaults against a person's bodily integrity or emotional well-being are antithetical to the values of a well-ordered society. Accordingly, a view that recognizes the crisis and danger of domestic violence is important. The state is uniquely well-situated to respond to an emergency or a crime related to the health, safety, and welfare of its citizens. In addition, the network of heavily statefunded, professionalized service providers that offer crisis hotlines, emergency shelters, and legal services provide important options for persons subjected to abuse to address any crisis moment of intimate partner abuse.

There are disadvantages to the safety paradigm, however. Emergencydriven measures designed to provide short-term physical protection ignore the range of supports necessary for a woman's long-term future. Indeed, some women who experience abuse may not be in physical danger, and are therefore served poorly or not at all by the panoply of remedies designed to provide physical protection.

A safety orientation also often impinges on women's agency and dignity. For instance, there are many reasons why women subjected to abuse do not take the course that the state deems the most safe-engaging the state to intervene through the criminal justice system. One reason is that mandatory arrest policies can deter women from calling 911 to help with the immediate situation because they may not want to subject their partners to automatic arrest and prosecution. For women of color, as Beth Richie writes, such a decision is a recognition of the "Prison Nation" that is at the intersection of race, gender, and domestic violence, where young black men are incarcerated at alarmingly high rates as a result of a racist penal system. ${ }^{120}$

Women also choose not to engage the state because, once they do, their opinion as to what would be the safest option for them and what would be the best outcome for them is often ignored. Separating from one's partner who is abusive can be extremely dangerous. ${ }^{121}$ For some women, they choose not to engage the state because they believe it to be the safest course of action. Research has shown that women are the best predictors of future assault. ${ }^{122}$

Michigan, Minnesota, Missouri, Mississippi, New Hampshire, New York, North Carolina, North Dakota, Oklahoma, Oregon, Pennsylvania, South Carolina, South Dakota, Tennessee, Texas, Utah, Vermont, Virginia, and Washington use program).

120. See Beth E. Richie, Arrested Justice: Black Women, Violence, and America's Prison Nation 46 (2012) (discussing how black women subjected to abuse avoid involving formal legal channels so they are not seen as adding to arrests of black men).

121. See Martha R. Mahoney, Legal Images of Battered Women: Redefining the Issue of Separation, 90 Mich. L. Rev. 1, 65-68 (1991) (defining "separation assault"); see also LONG ET AL., supra note 53, at 2-3.

122. See Johnson, Balancing Liberty, supra note 4, at 558-61 (discussing research showing women are best predictors of their future risk of assault). 
Further, women do not engage the state because they do not want their entire family to suffer the consequences of their partner's arrest or incarceration. ${ }^{123}$ Such actions could result in the loss of his job or the ability to get future employment, diminishment of the family income, loss of a partner in parenting the children, and loss of an intimate partner. ${ }^{124}$ Some of these women would prefer a way to end the abuse without ending the relationship through the criminal justice system. ${ }^{125}$

Another reason women choose not to involve or cooperate with the criminal justice system is because mandatory arrest policies make them less safe. Mandatory arrest laws became popular in the mid-1980s, upon the release of the Minneapolis Domestic Violence Experiment (MDVE) study that found arrests decreased the number of re-offenses of domestic violence. ${ }^{126}$ However, subsequent studies did not find the same results. ${ }^{127}$ The authors of the MDVE study showed that arrest might slightly decrease the rate of re-offense for those offenders who are married or employed, while increasing the rates of re-offense if the offender was unmarried or unemployed. ${ }^{128}$ The studies also showed that if the offender had prior assaults against his partner, or was drinking or using drugs at the time of the abuse, he was more likely to reoffend regardless of whether he was arrested. ${ }^{129}$ Therefore, arrest does not necessarily make persons subjected to abuse safer. ${ }^{130}$ Nonetheless, the mandatory arrest laws remain on the books and in practice based, in part, on the publicity around MDVE and its conclusion that such laws decreased future abuse. ${ }^{131}$ More-

123. See Buzawa \& BuzAwa, supra note 34, at 134-35 (explaining persons subjected to abuse may avoid arrest because they fear trauma to their family, future retaliatory abuse, economic impact, state discriminatory intervention against African Americans, including removal of children and disproportionate use of force and arrest against African Americans).

124. See Kohn, supra note 20, at 201-02, 228-29; see also Long ET AL., supra note 53, at 3 .

125. See Long ET AL., supra note 53, at 3.

126. See Univ. of Ky. Ctr. for Research on Violence Against Women, supra note 57, at 2; see also Buzawa \& Buzawa, supra note 34, at 94-98 (describing Minneapolis Domestic Violence Experiment); Kohn, supra note 20, at 213.

127. See Buzawa \& Buzawa, supra note 34, at 98-104.

128. See Univ. of Ky. Ctr. for Research on Violence Against Women, supra note 57, at 3; see also BuzAwa \& BuzawA, supra note 34, at 100-02 (detailing Milwaukee, WI study showing that arrests deterred employed but not unemployed offenders and discussing Miami, FL study showing that arrest coupled with problem-solving by trained staff with couple decreased re-offense rates for all but unemployed).

129. See Univ. of Ky. Citr. For Research on Violence Against Women, supra note 57 , at 2 .

130. See Kohn, supra note 20, at 238 (explaining mandatory interventions including mandatory arrest do not necessarily make individual subjected to abuse safer).

131. In part, the prevalence of mandatory arrest laws continues because VAWA required local and state agency applicants for grants to "certify that their laws encouraged or mandated arrests for domestic violence offenders . . . .” Buzawa \& Buzawa, supra note 34, at 121-22. 
over, mandatory arrest policies interfere with the ability of persons subjected to abuse to make choices for themselves about how to address the violence. ${ }^{132}$ This is a negative consequence because research shows that when women subjected to abuse are permitted to make their own decisions for how to address the violence, they identify greater life satisfaction and reduced violence in their lives. ${ }^{133}$ Another negative outcome of mandatory arrest is that police often arrest both parties when one party might not have committed a crime. For instance, one party may have assaulted the other in self-defense. ${ }^{134}$ Therefore, while having a criminal justice system response to domestic violence is critical and necessary to protect and support persons subjected to abuse, ${ }^{135}$ such a response also needs to address the needs and desires of persons subjected to abuse. ${ }^{136}$

There are similar downsides to no-drop prosecution policies as to mandatory arrest policies. First, the prosecution will go forward against the objections of the person subjected to abuse, despite the fact that it might increase her risk of being subjected to further abuse. ${ }^{137}$ Second, such policies result in fewer economic opportunities for the person being prosecuted as well as the person subjected to abuse. ${ }^{138}$ Third, because mandatory arrest policies often result in incarceration or no contact orders, such policies disrupt the ability of the person subjected to abuse to continue to maintain a relationship with the person who caused the abuse. ${ }^{139}$ By granting the person subjected to abuse the power to drop

132. See Univ. of Ky. Ctr. for Research on Violence Against Women, supra note 57 , at 4 .

133. See Johnson, Redefining Harm, supra note 5, at 1125-27. But see Univ. of Ky. Ctr. for Research on Violence Against Women, supra note 57, at 3 (citing study showing vast majority of women identified mandatory arrest as benefit because it took responsibility away from women to pursue arrest).

134. See Univ. of Ky. Ctr. for Research on Violence Against Women, supra note 57 , at 3 .

135. As Buzawa and Buzawa state, persons subjected to abuse "consistently wanted the police to respond to incidents, even if arrest was not always desired." Buzawa \& Buzawa, supra note 34, at 139 (noting women wanted offender controlled more often than arrested).

136. Data shows that given mandatory arrest policies, "police refuse[d] to follow the victim's request more frequently in domestic assault cases $(25 \%)$ than nondomestic assault cases (4\%). The victim disagreed with arrests made in $60 \%$ of domestic assaults compared with only $12 \%$ of nondomestic assaults . . ." Id. at 140 .

137. See id. at 183. (describing study finding $50 \%$ of "victims reported that their assailants had physically threatened them if they preceded further and attempted court [proceedings] ....").

138. See id. at 183-84 (citing victims' fears of financial loss potentially incurred through participating in prosecution of assailant or resulting from assailants' incarceration or termination from employment).

139. See id. at 182 (citing research showing that victims chose not to cooperate in prosecution because they are "far less concerned with deterrence as an esoteric concept than with using the criminal justice system as a whole to accomplish personal goals of enhancing safety, maintaining economic viability, protecting chil- 
charges, the government would equip her with "the threat of continued prosecution as a "victim power resource." 140

Further, a criminal trial results in punishment that may provide no meaningful remedy for the person subjected to abuse. The defendant may be incarcerated or fined, however, none of these outcomes provide an immediate or tangible benefit for the person subjected to abuse, and in fact, they can be harmful. ${ }^{141}$ The no-drop policy intentionally dehumanizes the person subjected to abuse and discounts her agency and dignity by requiring the prosecutor to proceed against her will. ${ }^{142}$ Studies on nodrop prosecution show that "enhancing the empowerment of the victim [including permitting victims to drop charges], rather than the actual prosecution, may be a key factor" in reducing re-abuse. ${ }^{143}$ Accordingly, while it is important to have a criminal justice system available to prosecute domestic violence crimes, such prosecution, similar to the arrest decision, should be informed by and responsive to the needs and desires of the person subjected to abuse. ${ }^{144}$

There are also similar positive and negative consequences to criminal no contact orders. If the person subjected to abuse wants the stay away order, it can be a useful response to the violence. However, once issued, only the state can control whether the order is lifted prior to its expiration. A response that provides more control to the person subjected to abuse would be a stay away or no contact order in the civil protective order case, which should remain more in her control.

Other negative consequences of criminal no contact orders arise when they are issued against the wishes of the person who was subjected to the abuse at issue in the criminal case. For instance, research shows that criminal no contact orders do not stop future abuse and can harm wo-

dren, or having an opportunity to force participation in batterers' counseling programs").

140. Id. at 201.

141. See Univ. of Ky. Ctr. for Research on Violence Against Women, supra note 57 , at 4 .

142. See Buzawa \& Buzawa, supra note 34, at 198 ("As one prosecutor explained, if the victim recants, the proper prosecution for domestic abuse cases is similar to a homicide ...."). Many scholars trace victims' refusal to cooperate with the prosecution to the Battered Women's Syndrome and Learned Helplessness theories as well because such theories reinforce the state's idea that women subjected to abuse are "passive [and] victimized" and should "not be seen as active partners in domestic violence interventions." Kohn, supra note 20, at 208 (citing Elizabeth M. Schneider, Particularity and Generality: Challenges of Feminist Theory and Practice in Work on Woman-Abuse, 67 N.Y.U. L. Rev. 520, 561 (1992)); see also Friedman \& McCormack, supra note 85, at 1188-89 (noting no-drop policies assume that women subjected to abuse suffer from false consciousness regarding their risk of danger).

143. Buzawa \& Buzawa, supra note 34, at 202.

144. See id. at 201 (“[M]any women may be safer if they can freely drop actions but ultimately may be less safe if they do.... [V]ictims need to be treated as full partners in the prosecution of the case."). 
men. ${ }^{145}$ As discussed in a model policy for courts and prosecutors regarding no contact orders, "research has shown that, in some cases, a victim's separation from an abuser actually increases the risk of lethality. The decision by the prosecutor or the court to restrict contact between a batterer and his victim does not always achieve the system's goal of victim protection and safety." 146 In addition, research shows that, because a mandatory criminal no contact order issued against the will of the person subjected to abuse is detrimental to her agency, it also negatively impacts her safety. ${ }^{147}$ Finally, criminal no contact orders issued against the will of a married victim create a sua sponte divorce of the spouses by the court. ${ }^{148}$

The civil protection order laws permit a person subjected to abuse to obtain an injunction against the offender in the form of a stay away order, no contact order, or some form of exclusion from the home. ${ }^{149}$ A positive consequence of the CPO laws is that they can support the agency of persons subjected to abuse: petitioners can choose to file the case, they choose what acts of abuse to include in the petition, they choose what remedy to select, and they choose for how long they will request the order be in place. ${ }^{150}$ A negative consequence of the CPO laws is that they constrain the extent of the petitioner's control, as they are often limited by statute to a period of one year, ${ }^{151}$ and they do not cover all forms of abuse. ${ }^{152}$ In addition, as discussed above, courts may intervene and undermine the agency of persons subjected to abuse by ordering them to separate from the person who has abused them, even if that was not the relief requested. ${ }^{153}$ Further, courts may refuse to permit the person subjected to abuse to dismiss her petition for a protective order, even if she believes it is in her best interest to do so. ${ }^{154}$ Some studies have shown that the CPO can be an effective tool in reducing domestic violence or achiev-

145. See id. 242-43 (showing criminal stay away orders issued against will of person subjected to abuse do not prevent re-abuse); see also LONG ET AL., supra note 53 , at 2 .

146. LONG ET AL., supra note 53, at 2 (footnote omitted).

147. See Friedman, supra note 48, at 249 (citing Christine O'Connor, Note, Domestic Violence No-Contact Orders and the Autonomy Rights of Victims, 40 B.C. L. REv. 937, 962 (1999)).

148. See Suk, supra note 21, at 43-44.

149. See Johnson, Redefining Harm, supra note 5, at 1131.

150. See id. at 1128-29.

151. See Klein \& Orloff, supra note 69, at 1085-88 (noting majority of state CPO laws limit orders to one year, with several states permitting orders for two to three years, and few states permitting them to last indefinitely); see also ABA Comm'n on Domestic Violence, Domestic Violence Civil Protection Orders (CPOs) BY STATE (July 2008), available at http://www.americanbar.org/content/ $\mathrm{dam} / \mathrm{aba} /$ migrated/domviol/docs/DV_CPO_Chart_8_2008.authcheckdam.pdf.

152. See Johnson, Redefining Harm, supra note 5, at 1130-38.

153. See Goldfarb, supra note 74, at 1504-05.

154. See Kohn, supra note 20, at 225-34; Kuennen, supra note 20, at 52-53. 
ing the goals of the petitioner for the CPO. ${ }^{155}$ Other studies show that CPOs are only effective for a segment of petitioners, similar to mandatory arrest. ${ }^{156}$ Moreover, CPOs are most effective when they effectuate the goals of the petitioner herself. ${ }^{157}$

The availability of emergency domestic violence shelters can be critical for persons subjected to abuse. It is important to have housing available for a person subjected to abuse who decides that she needs to leave her home in order to address the abuse. Shelters offer a necessary option for persons experiencing abuse and trying to decide how best to address it. In this way, shelters are the quintessential short-term remedy for physical violence through physical separation and show how necessary certain options in this safety model can be.

However, as discussed above, there are limits to the benefits of the shelter system's operating model of total physical separation. A 2001 study shows that separation of the parties does not reduce partner homicide. ${ }^{158}$ In fact, some of the findings showed that resources focused on physical separation can be incredibly dangerous to persons subjected to abuse. ${ }^{159}$ This dangerousness is due to the fact that focusing only on physical separation ignores the reality of the partners' interconnected lives-sharing children, property, friends, and communities-and, therefore, separation may not be a true option. ${ }^{160}$ Further, the risk of violence may continue after leaving the shelter. In one study, almost half of all women experienced continued domestic violence within a short time after leaving a shelter. ${ }^{161}$ Accordingly, the shelter model of total physical separation can be lethal because separation may not be possible, safe, or desired at that particular time.

Other aspects of the shelter system are also detrimental for persons subjected to abuse. The confidential nature of many shelters disconnects persons subjected to abuse from their support networks. While in the shelter, women cannot disclose their location and are often unable to maintain contact with the person who abused them. ${ }^{162}$ What research

155. See Johnson, Redefining Harm, supra note 5, at 1128-29 (showing that CPOs are effective in decreasing future violence).

156. See Jane Aiken \& Katherine Goldwasser, The Perils of Empowerment, 20 CoRNell J.L. \& Pub. Pol'y 139, 158-59 (2010) (explaining CPOs are less effective on "men with prior criminal histories, men who are unemployed, and men who have substance abuse problems" (footnotes omitted)).

157. See Johnson, Redefining Harm, supra note 5, at 1124-29.

158. See Johnson, Balancing Liberty, supra note 4, at 573.

159. See id.

160. See Goodman \& Epstein, supra note 8, at 102.

161. See Johnson, Home, supra note 15, at 44 (citing Cris M. Sullivan \& Maureen H. Rumptz, Adjustment and Needs of African-American Women Who Utilized a Domestic Violence Shelter, 9 Violence \& Victims 275, 281 (1994) (noting forty-six percent of women experienced further domestic violence within ten weeks of leaving the shelter)).

162. See Goodman \& Epstein, supra note 8, at 112. 
shows, however, is that because hidden shelters isolate women from their community and the security that comes from being a part of a neighborhood, women's risk of experiencing violence increases. ${ }^{163}$ "As Professors Epstein and Goodman explain, 'research shows that women in hidden locations are no safer during their stay than women in open shelters where community members can participate in keeping residents safe." 164 The negative effect of separation from a shelter stay was documented in a study of Puerto Rican women, which found that the women "'don't want to leave their community and come to a new place. They may have language problems. They don't drive. They may never have paid bills or done a budget. . . . They're not used to living collectively or sharing apartments like white women do." "165

Shelters often require that a resident be female, thereby excluding men and transgendered women, resulting in fewer temporary homes for persons subjected to abuse and fortifying a "worthy victim" stereotype. ${ }^{166}$ To rectify this gap in services, some advocates have suggested creating shelters for men who experience intimate partner violence. ${ }^{167}$ Similarly, anti-discrimination laws protecting transgendered persons have helped to open up some shelters to transgendered women. ${ }^{168}$

Finally, it is problematic that shelters operating under the safety paradigm are the party dictating the appropriate response to domestic violence rather than the person subjected to abuse. One study has shown that women subjected to abuse found services provided in a woman-centered manner that permitted the women to be the decision makers produced "'good social support networks, fewer feelings of isolation, and better access to childcare after receiving assistance.'"169 When services were woman-centered, included active listening, and respected the woman's ability to make decisions, the services were most effective. ${ }^{170}$ The least helpful were services that told the woman what to do in response to the abuse and criticized her decisions. ${ }^{171}$

163. See Johnson, Home, supra note 15 , at 38.

164. Id. (quoting GoOdman \& Epstein, supra note 8, at 102).

165. Id. at 38 n.159 (quoting Schechter, supra note 41, at 59).

166. See Tara J. Palmatier, Domestic Violence Awareness Month: The Invisible Victims, A Voice for Men: Humanist Counter-Theory (Oct. 1, 2013), http://www .avoiceformen.com/mens-rights/activism/domestic-violence-awareness-month-theinvisible-victims/ (stating that there is only one shelter for men subjected to domestic violence, Valley Oasis Shelter in Antelope, CA).

167. See id.; see also Crick, supra note 84, at 1059 (discussing lack of services for men in Washington State and proposals for addressing them).

168. See Goodmark, supra note 84, at 70-71.

169. Johnson, Redefining Harm, supra note 5, at 1126 (quoting Angela Moe Wan, Battered Women in the Restraining Order Process: Observations in a Court Advocacy Program, 6 Violence Against Women 606, 611 (2000)).

170. See Johnson, Balancing Liberty, supra note 4, at 572-73.

171. See id. at 572 . 
As seen in the previous section, federal funding is heavily skewed towards safety paradigm programs. As a result, it is no surprise that the majority of state-legislated programs also focus on funding safety paradigm programs. It is important that violence against women is recognized by the state and federal governments and that the responses to the abuse are well-funded. However, as seen in the above discussion, the funding of certain programs, such as mandatory arrest and no-drop prosecution, does not necessarily effectively address the state's interest in "safety;" as such, programs may increase or have no effect on future abuse. Moreover, increased safety programs that override the choices of persons subjected to abuse, such as the lethality assessment program, may cause significant harm to women by decreasing their safety and negatively impacting their dignity and agency. ${ }^{172}$

Mary's story ${ }^{173}$ from the beginning of this Article demonstrates some of the positive aspects of the safety paradigm while highlighting the very problematic results of not having a security paradigm. First, from Mary's story, we learn that only her physical abuse was recognized under the CPO law and under the crime victims compensation fund (CVC), which provided the monies for the shelter, transportation vouchers, and food vouchers. As a result, the other forms of abuse to which she was subjectedemotional, psychological, economic, and medical-were not recognized or addressed by the court or the CVC officers. Because of the physical violence, however, she was able to gain emergency short-term relief based on physical separation, which she desperately needed, such as emergency shelter, emergency medical treatment, temporary transportation and food vouchers, and a CPO for one year. This relief is one of the great successes of the current domestic violence movement. As a result, Mary initially felt "safe" through this court-ordered and community-based support for her physical separation from her ex-partner.

But this almost textbook safety was not at all secure in the short- or long-term. As Mary recounted, yes she had left Todd, and she had an order that said he could not harm her, but she had no job, no housing after thirty days, ${ }^{174}$ no money for food after thirty days, no medicine, and no clothes other than what she left the home wearing. After her shelter stay, she was left with no choice but to return to Todd.

The question raised by Mary's experience is whether there is any other way to construct the response to intimate partner abuse that can be better at effectuating choices of women subjected to abuse to lead secure lives. This Article argues that the security paradigm offers such a construction.

172. See generally id.

173. See supra notes $2-3$ and accompanying text.

174. Similar to Mary's experience, most shelters limit residents' stays to thirty days in length. See Johnson, Home, supra note 15, at 43. 


\section{Towards a Security Paradigm}

There is another paradigm to address domestic violence that maintains the benefits of the safety paradigm while mitigating its harms. Premised on a broad, research-based understanding of "domestic violence" as "intimate partner abuse," this is the security paradigm.

\section{A. The Security Paradigm}

As reflected above, a "safety-at-all-costs" orientation impinges on women's agency, dignity, and well-being in a way that may inadvertently and counterintuitively make women less safe. A different approach to addressing domestic violence would be to re-orient the system to prioritize women's overall well-being, in addition to their physical safety, and to do so in a women-centered manner, based on their views of what will increase their well-being.

The security paradigm has four main components. First, the security paradigm recognizes all forms of intimate partner abuse, including physical, sexual, psychological, emotional, and economic abuse. It recognizes the coercive use of power and control in an intimate partner relationship as key to the abuse. In other words, the security paradigm recognizes actions that coercively constrain or aim to constrain an intimate partner's liberty, dignity, and agency. Second, the security paradigm recognizes all forms of harm that result from the range of abuse. Therefore, the security paradigm recognizes physical injury as well as psychological trauma, lack of economic resources, and isolation. Third, the security paradigm seeks to create multiple options to address the abuse and harm. These options are both short-term responses focused on true physical safety as well as short-term and long-term responses focused on economic, housing, health, and relationship security. Fourth, the person subjected to abuse remains the decision maker in responding to all of the circumstances in her life, including decisions in the context of the abuse she has experienced. The state and other institutions' role will be to help generate and support options consistent with the security paradigm and help facilitate her decision making. To this end, the security paradigm recognizes the range of motivations and goals she may have in addressing the abuse, including the fact that ending the relationship may not be her goal and addressing the abuse may be weighed against other important goals, such as the economic security of her children.

Security can be accomplished by implementing measures designed to promote women's economic security, housing security, health security, and relationship security, in addition to the physical safety of a woman subjected to abuse. For example, economic security would entail having a steady full-time job with a reliable and livable income, reliable public benefits, predictable and manageable living expenses, and the accumulation of some assets, such as a home, a car, and some money in savings. If she does not have a job currently, economic security includes career counsel- 
ing, education, job training, and child care to assist the woman in obtaining job security. Economic security would also entail access to monetary damages and restitution for any and all harm resulting from the abuse, as well as adequate family support if the woman lives separately from her partner because of the abuse.

Economic security would also include eliminating and remedying employment discrimination against persons who have been subjected to abuse. When women subjected to abuse are unemployed because of the abuse, unemployment benefits would provide economic security.

Economic security permits a woman subjected to abuse to make true choices about how she wants to address the abuse in her relationship. With economic security, she need not choose to stay in an abusive relationship simply because her partner earns the family's money and without him she will not be able to keep her home or support her children. With economic security as well as job security, she may have more mental, emotional, and physical strength to problem solve around the abuse in her relationship.

Housing security is the ability to control one's housing, whether it be having a home titled in her name, being the mortgagor for a home, or being the tenant in an apartment. Such housing should be affordable and stable, such that it can be on a long-term basis if that is what she wants. Housing security would address and remedy any housing discrimination resulting from the abuse. Similarly, housing security includes, after abuse occurs, the ability to decide whether to remain living in her home, whether to vacate her partner from the home, and whether options for short- and long-term affordable alternative housing are available if she chooses to leave the home. Housing security offers stability that has the potential to reinforce her agency in determining how best to rearrange her relationship to address satisfactorily the violence, while either ending or continuing her relationship.

Similarly, health security means that a woman has access to adequate medical and mental health care for herself and her dependents, including regular preventive care, access to affordable medications, access to specialists when necessary, and transportation to and from appointments. ${ }^{175} \mathrm{~A}$ woman who has these things can maintain her physical and mental health, engage in typical activities of daily living, including self-care, and maintain the independence, agency, and vitality required to satisfy her responsibilities and contribute to the best of her abilities.

Relationship security is having relationships that are stable, healthy, respectful, and supportive of each individual's agency and dignity. The

175. According to the United Nations Development Programme's 1994 Human Development Report, health security includes "a primary health care approach, emphasizing community involvement, self-sufficiency and protection of vulnerable groups such as pregnant women and the poor." William Aldis, Health Security as a Public Health Concept: A Critical Analysis, 23 Health Pol'y \& Plan. 369, 373 (2008). 
relationships include relationships with intimate partners, children, other family members, friends, and neighbors. Relationship security includes the ability to choose to stay in her community, connected to all supportive aspects of her community, such as her place of worship, her neighborhood and neighbors, and other social networks or resources. Relationship security acknowledges the importance of social capital, the interdependence of people, and the benefits of building and maintaining a social network upon which she can rely for assistance as she continues to build her future life.

\section{B. Focusing on Security Will More Effectively Address All Types of Intimate Partner Abuse and Their Harms}

A focus on security looks at all well-being indicia for the person subjected to abuse-her agency, dignity, liberty, and health. A focus on security can thereby take into account all types of intimate partner abuse, not just physical, but also economic, emotional, and psychological abuse. A focus on security can generate options to address the broad spectrum of coercive abuse while supporting a woman's effort to obtain economic, housing, health, and relational security. For instance, as Dana Harrington Conner describes, a woman may be targeted by her partner for economic abuse because she is economically unstable, with limited income or no home of her own. ${ }^{176}$ The security paradigm would foster and support state, institutional, and community-based options-funded in part by state money that is currently allocated to ineffective safety initiatives. These provisions would support empowerment-focused career counseling, while also encouraging social capital creation through time banking. This initiative would also identify potential jobs and address obstacles to obtaining employment, ranging from transportation to child care.

The security paradigm can look at policy through the lens of addressing and remedying the harms of intimate partner abuse and, specifically, coercive control, as identified by the person subjected to abuse. As such, security permits us to focus on the varied actions taken or contemplated by persons subjected to abuse to address the abuse rather than measures taken on her behalf by others. The actions taken by a person subjected to abuse include her proactive and responsive deployment of the state, her community, and local service providers as well as her decisions about her relationships. On the other hand, in the safety paradigm, a person subjected to abuse has no choice regarding the mandatory arrest or prosecution following a 911 call and no control over a criminal no contact order issued by the court. Under the security paradigm, the person subjected to abuse may choose to have the person committing the acts of abuse arrested to stop the abuse in the instant and then decide she either does not want him to be prosecuted or does not want a no-contact order to be issued. She may make these decisions for a myriad of reasons, perhaps be-

176. See Conner, supra note 36 , at 359-60. 
cause she wants to continue living and managing her family together or because the criminal justice system response will not meet any of her goals. In fact, the criminal justice system response may exacerbate problems such as poverty or racial oppression through incarceration and its effect on his economic livelihood. ${ }^{177}$

All types of intimate partner abuse can-and often do-affect the economic life of the person experiencing the abuse. For instance, domestic violence is the leading cause of family homelessness. ${ }^{178}$ The cause of this is as multifaceted as the abuse itself. For instance, "[m]any abusers so isolate and demoralize their victims that the victims are left with few support systems, and hence have great difficulty getting on their feet . . ."179 Often, the woman experiencing abuse is economically dependent on her abuser's income, lacks access to other sufficient resources, and suffers from decreased physical and mental health that negatively affects her ability to gain adequate employment. ${ }^{180}$ Also, if the abuser is separated from the woman through the civil legal system, "his income often leaves with him despite orders that he pay child support and maintenance. Some women are reluctant to insist upon the payments because they believe that they may be at greater risk of retaliation and violence if they make such demands." 181 If the abuser is convicted and incarcerated for his abuse, the criminal court has no jurisdiction to issue child or spousal support to the woman who experienced the abuse. During his incarceration, he is no longer employed and earning an income to support her, and his future employment is jeopardized with his criminal record. ${ }^{182}$ If he is an immigrant, his conviction can result in deportation, which further jeopardizes his ability to offer financial support to her and their children. ${ }^{183}$ As a result, the woman subjected to abuse may be in or on the edge of poverty, ${ }^{184}$ and as mentioned above, at risk of becoming homeless. ${ }^{185}$ Further, if she was isolated through the abuse, she may not have had access to or sought out medical or mental health professionals to help her with the

177. See Richie, supra note 120, at 121-22 (explaining black women's lack of reliance on criminal legal system).

178. See Johnson, Home, supra note 15, at 13; see also Preventing Domestic Violence Survivors from Becoming Homeless, Nat'L L. CTr. on Homelessness \& Poverty, http://www.nlchp.org/prevention (last visited Jan. 19, 2015).

179. Aiken \& Goldwasser, supra note 156, at 160.

180. See Johnson, Redefining Harm, supra note 5, at 1123; see also Aiken \& Goldwasser, supra note 156, at 160 (noting women's employment is often at great risk because of abuse).

181. Aiken \& Goldwasser, supra note 156, at 160.

182. See Bailey, supra note 21, at 1794-96.

183. See id.

184. See id. at 1794 ("A domestic violence victim faces a fifty percent chance her income will fall below the poverty level if she leaves her batterer.").

185. See Johnson, Redefining Harm, supra note 5, at 1123; see also Aiken \& Goldwasser, supra note 156, at 160 (noting women's employment is often at great risk because of abuse). 
abuse, any resulting depression, and other related issues. ${ }^{186}$ Instead, if she turned to substance abuse to treat her mental health issues, any "substance abuse issues may hinder the woman from being able to maintain full-time work, provide adequate care for children, or seek appropriate services that will assist in her recovery from the abuse."187 Accordingly, focusing on security is important to address all harms from all forms of abuse.

\section{Focusing on Security Will Support the Agency, Dignity, and Resilience of Persons Subjected to Abuse}

A security focus more effectively addresses domestic violence because it more comprehensively supports the agency and dignity of the person subjected to abuse. ${ }^{188}$ Agency is making "choices, acts of resistance, selfdirection, and self-definition."189 "Dignity is the inherent nature that renders human beings capable of autonomous action and thought." 190 Dignity recognizes people as separate from the state, with the rights and responsibilities to exercise their agency to address "fundamental questions touching the meaning and value of their own lives." 191 To support dignity, society must respect and support individuals' capabilities such as rationality; "life; bodily health; bodily integrity; senses, imagination and thought; emotions; practical reason; affiliation; respect for other species; play; and control over one's environment." 192 Supporting one's dignity is an important endeavor because it is linked to the greater satisfaction and happiness of the person subjected to abuse, even when she continues in a relationship with her abuser. ${ }^{193}$ Security lets persons subjected to abuse be an agent-to identify their own goals regarding the abusive relationship and their life satisfaction and to make informed decisions to achieve their goals without outsiders defining dangers and havens for them. When we shift the frame to security from safety, we permit the goals of the person subjected to abuse to drive the options that exist externally and internally. When these goals come into focus, we can see that they are complex and multiple, driven by the woman's whole life experience, not just a decontextualized act of abuse. Research shows that violence may decrease when women subjected to abuse are able to connect to their

186. See Aiken \& Goldwasser, supra note 156, at 161-62.

187. Id. at 162.

188. See Johnson, Home, supra note 15, at 16-17 (discussing importance of supporting agency and dignity to appropriately address domestic violence).

189. Margaret E. Johnson, "Avoiding Harm Otherwise": Reframing Women Employees' Responses to the Harms of Sexual Harassment, 80 Temp. L. Rev. 743, 753 (2007) (citing Abrams, supra note 5, at 111, 113). See generally Johnson, Redefining Harm, supra note 5.

190. Johnson, Home, supra note 15 , at 9-10.

191. Id. at 10 (quoting Dworkin, supra note 4, at 426).

192. Id. at 11 (citing Martha Nussbaum, Human Dignity and Political Entitlements, in Human Dignity and Bioethics: Essays Commissioned by the President's Council on Bioethics (2008)).

193. See id. at $16-17$. 
community, control their physical environment by leasing or owning their own home, and build assets, such as home ownership or a small business. ${ }^{194}$ And when persons subjected to abuse make their own informed choices about physical separation or what is safe, they are more satisfied with their life and less at risk of physical violence. ${ }^{195}$ Moreover, agency fosters resilience, a necessary feature for addressing abuse in one's life.

Researchers have shown that women who experience intimate partner abuse often decrease their exposure to violence when they exercise their own agency. ${ }^{196}$ As domestic violence is the systemic operation of power and control, " "[a]n important element of responding to the problem [of domestic violence] is to restore a victim's fundamental rights of freedom, choice and autonomy." 197 For example, a woman exercises her agency when she decides to obtain a civil protection order that will provide the specific relief she is seeking, perhaps in a form as simple as an injunction against further abuse or as complicated as orders for child custody, child support, eviction of the abusive partner from the home, or an injunction against any contact. ${ }^{198}$

On the other hand, when a landlord or employer requires a woman subjected to abuse to obtain a CPO in order to avoid eviction or termination, the woman's agency is constrained by seeking a CPO she would not have otherwise sought. In addition, a woman is unable to exercise her complete agency when the court refuses to grant a civil protection order unless the woman reluctantly requests an injunction against physical contact. ${ }^{199}$ Such constraints on agency are not uncommon. All agency is circumscribed by the context in which we live and the systemic operation of power. For a security paradigm focused on supporting women's agency, we should focus on supporting women's exercise of agency that is most linked to a decrease of intimate partner abuse: her complete agency that is decided upon by her and that is countervailing to the systemic operation

194. See id.

195. Cf. supra notes 52-119 and accompanying text.

196. See Johnson, Home, supra note 15, at 16-17.

197. Johnson, Redefining Harm, supra note 5, at 1151 (second alteration in original) (quoting Tamara L. Kuennen, Analyzing the Impact of Coercion on Domestic Violence Victims: How Much Is Too Much?, 22 Berkeley J. Gender L. \& Just. 2, 30 (2007)).

198. See id. at 1131 (describing various remedies available under civil protection order statutes).

199. See id. at 1150. Research shows that leaving an abusive relationship can be more dangerous for women because it "may increase stalking, harassment, and may decrease the woman's ability to influence him." Id. at 1127 (citing LeNORE E. A. Walker, Abused Women and Survivor Therapy: A Practical Guide for the Psychotherapist 55 (1994)). Separation Assault, as it is known, results from the abuser losing control over his victim and lashing out with increased violence. See GoOdman \& Epstein, supra note 8, at 97-98; Aiken \& Goldwasser, supra note 156, at 162. Because separation assault is common, it is critical that the woman is the one making the decision to exercise her agency in light of the abusive relationship and her objectives, as she is in the best position to predict her risk of danger. See Johnson, Balancing Liberty, supra note 4, at 558-61. 
of power, especially that of the domestic abuse. Therefore, outsiders forcing action by the woman, rather than permitting her to make the informed choice about which action to take, can be counterproductive.

Institutional actors can promote and support women's agency by expanding options for women to choose in their efforts to address the intimate partner abuse. ${ }^{200}$ One study explored the agency of low-income Puerto Rican women who were living with abusive partners. ${ }^{201}$ The study found that when the women decided to rent and control their own apartments, they were able to decrease their exposure to violence. The study found that this decrease in violence occurred even when the women continued their relationships with the partners who had been abusive. ${ }^{202}$ Another study shows that women who received autonomy-respecting "support and assistance" during a CPO proceeding "thought more positively about the proceedings" and "reported having good social support networks, fewer feelings of isolation, and better access to child care after receiving assistance." 203 The options can-and should-include criminal justice and civil legal system responses that provide physical separation for either safety or punitive purposes. But, to effectuate agency and thereby decrease future violence, the woman should be provided the opportunity to make these decisions based upon her experience of the violence, her prediction of the risk, and her determination of options that would increase her life satisfaction.

The person subjected to abuse may not be able to achieve her goals if she does not have real options-either because she has limited economic resources or because our system has not chosen to fund other options because they do not fit the "safety" paradigm.

Accordingly, a focus on security more effectively addresses intimate partner abuse because it offers more avenues to address intimate partner abuse, ensuring the economic, housing, health, and relationship security of the woman subjected to abuse. Further, I define security in this Article as requiring that the person subjected to abuse, not the state or other institution, is the decision maker as to which options to choose to best address the abuse. ${ }^{204}$ Built into the security paradigm is a recognition of the agency and dignity of the person subjected to abuse.

200. See Johnson, Redefining Harm, supra note 5, at 1151.

201. See Sherri Lawson Clark et al., Housing Dependence and Intimate Relationships in the Lives of Low-Income Puerto Rican Mothers, 32 J. FAm. Issues 369, 371-73 (2011).

202. See id. at 385 ("Mothers [ ] interpreted housing as a valued resource in intimate partner relationships in divergent ways with independent housing being seen as a bargaining tool to maintain or initiate relationships as well as a refuge for terminating relationships that experienced conflict.").

203. Wan, supra note 169 , at 611.

204. See supra Part III.A. 


\section{Focusing on Security Will Increase Access to Resources}

A security-focused approach to address domestic violence emphasizes increased access to economic, housing, health, relationship, and other resources for persons subjected to intimate partner abuse. As Dana Harrington Conner discusses, "[f]inancial independence [for the person subjected to abuse] shifts power within the intimate relationship."205 Without such independence, one is vulnerable to a controlling or abusive partner whether the person wants to remain in the relationship or leave it. ${ }^{206}$ Jody Raphael documented that women on welfare experience intimate partner abuse at four to five times the rate of all women. ${ }^{207}$ Donna Coker analyzed a body of research showing the inextricable link between access to economic resources and intimate partner abuse. For instance, Coker analyzed research conducted by Cris Sullivan, showing the connection between financial resources, future violence, and overall well-being. ${ }^{208}$ The study evaluated two groups of women who had been subjected to abuse and were set to leave a shelter. The control group received no services upon leaving the shelter, while the other group of women was provided with an advocate who assisted the women in accessing "educational resources, legal assistance, employment, services for their children, housing, child care, transportation, financial assistance, health care, and social supports." ${ }^{209}$ These resources were provided in a woman-centered manner based on the women's individual goals, not state or institutional goals. As a result of this access to resources, the women experienced significantly reduced psychological abuse, fewer mental health issues, greater social capital, higher quality of life, and no physical abuse. ${ }^{210}$ These results were in stark contrast to the control group. ${ }^{211}$ Similarly, JoAnn Miller and Amy Krull found that persons subjected to abuse who were unemployed experienced greater rates of recurring abuse than those who were employed. Two other studies showed that the length of unemployment correlated with the rate at which abuse reoccurred. ${ }^{212}$ In addition, a study by Amy Farmer and Jill Tiefenthaler showed that, as women's in-

205. Conner, supra note 36 , at 374 .

206. See Coker, Economic Rights, supra note 9, at 188 ("Inadequate material resources render women more vulnerable to violence. Inadequate material resources increase the batterers' access to women who do try to separate. Inadequate material resources are a primary reason why women do not try to separate.").

207. See Jody Raphael, Saving Bernice: Battered Women, Welfare, and PovERTY 5 (2000) (analyzing overrepresentation of women subjected to abuse in population of women receiving welfare).

208. See Coker, Shifting Power, supra note 24, at 1022-23.

209. Id. at 1022.

210. See id. at 1022-23.

211. See id.

212. See id. 
come increases, the rate of domestic violence decreases, except for women in the highest income bracket. ${ }^{213}$

Accordingly, the relative economic power within a relationship is correlated to occurrence of abuse. Yet it is important to understand that neither the woman nor the couple is an economically autonomous entity. Both need to be viewed within the broader context of their friends, family, neighbors, community, and society and the way in which they interact with the larger system of economic dependencies and resources. ${ }^{214}$ In her examination of economic security of women subjected to abuse, Kameri Christy-McMullin's research shows that there are "six overlapping components of economic security: public assistance, education, employment, income, assets, and divorce and child custody settlements." 215 Accordingly, this section examines the research regarding the relative economic power within the relationship, including access to public benefits, education, employment, income, assets, and family law support, including civil protective orders.

As discussed by Christy-McMullin, the first area of economic security is public assistance. There are multiple government assistance programs that are intended to provide those in poverty with a safety net and security. Unfortunately, as many have documented, the public safety net has shrunk since the welfare reforms of 1996. For instance, Temporary Assistance for Needy Families (TANF) replaced Aid to Families with Dependent Children (AFDC) and placed a five-year cap on cash assistance. TANF also instituted work requirements, narrowed educational waivers, and narrowed other waivers of the cap. ${ }^{216}$ As Michele Gilman documents, TANF has not decreased the numbers of those experiencing poverty but rather has "pushed many poor mothers into the low-wage workforce, where they struggle to survive on meager wages." ${ }^{17}$ Yet, even those who might benefit from the minimal monthly average assistance of $\$ 429$ do not receive the assistance because of the bureaucratic and arbitrary gatekeeping of the

213. See Christy-McMullin, Designing Policies, supra note 9, at 113 (citing Amy Farmer \& Jill Tiefenthaler, An Economic Analysis of Domestic Violence, 55 Rev. Soc. Econ. $337(1997))$. Farmer and Tiefenthaler's study also showed that violence increased with an increase in the man's income level. See id.; see also Kameri Christy-McMullin, An Evidenced-Based Approach to a Theoretical Understanding of the Relationship Between Economic Resources, Race/Ethnicity, and Woman Abuse, 3 J. EviDENCE-BASEd Soc. Work 1, 23 (2006) [hereinafter Christy-McMullin, An EvidenceBased Approach] (explaining that studies examining relationship between economic resources and woman abuse provide mixed results, showing three recent studies demonstrate significant relationship between economic resources and abuse, while two older studies show no significant relationship).

214. See Coker, Shifting Power, supra note 24, at 1024.

215. Christy-McMullin, Designing Policies, supra note 9, at 111.

216. See Michele Estrin Gilman, The Return of the Welfare Queen, 22 Aм. U. J. Gender Soc. Pol'y \& L. 247, 247, 249 (2014); see also id. at 254-56 (providing helpful summary of TANF work requirements).

217. Id. at 249. 
TANF program and its workers. ${ }^{218}$ The net result is " 4.5 million people receive cash assistance through TANF (amounting to $0.47 \%$ of the federal 2012 budget) . . .."219 As such, TANF is a very small public assistance program, with capped spending at $\$ 16.5$ billion. ${ }^{220}$

Moreover, although the numbers of people receiving TANF cash assistance have decreased, "poverty and unemployment rates have increased."221 The unemployment rates for TANF recipients are explained in part due to the higher number of barriers to work that TANF recipients face, including "lack of education, mental or physical disabilities, substance abuse or alcoholism, limited work experience, and caregiving responsibilities for disabled children." 222 The poverty rates are explained in part because "income gains from employment are often reduced by the loss of public benefits and are eaten up by the very costs of working-child care, transportation, uniforms, and other expenses."223 Thus, even healthy individuals experiencing poverty with some degree of higher education and a work history experience difficulty gaining economic stability. ${ }^{224}$ Additionally, the Supplemental Nutritional Aid to Families Program (SNAP), otherwise known as food stamps, benefits 46 million people. ${ }^{225}$ Even when families receive TANF and SNAP benefits, however, most of those families remain below the poverty line. ${ }^{226}$ Further, single mothers have a higher unemployment rate than in the past. ${ }^{227}$

The largest public assistance program is the Earned Income Tax Credit (EITC), which provides a tax credit for low-income working persons. In 2011 , the EITC provided $\$ 58.6$ billion to 26.2 million families, helping millions rise out of poverty. ${ }^{228}$ To receive this assistance, however, one must be employed. There are other public assistance programs as well, which are more fully-discussed below in Part IV.E.

The second area of economic security is education, as discussed by Christy-McMullin. Education serves as an important tool for increasing opportunities for employment. ${ }^{229}$ Access to education can increase one's employment opportunities and thereby increase one's economic resources. As part of the isolation that may result from the abuse, a woman may not have been permitted to complete or pursue education that would have enhanced her employment marketability. For low-income women,

\author{
218. See id. \\ 219. Id. \\ 220. Id. at 267. \\ 221. Id. at 269. \\ 222. Id. at 270 . \\ 223. Id. \\ 224. See id. \\ 225. See id. at 248, 268. \\ 226. Id. at 268. \\ 227. See id. at 269-70. \\ 228. See id. at 267. \\ 229. See Conner, supra note 36 , at 386.
}


another barrier to education has been TANF regulations that permit only $30 \%$ of a state's recipients to be exempted from the work requirements to pursue education, and even that exemption is limited to vocational training or completion of high school. ${ }^{230}$ Christy-McMullin's research shows that having at least a four-year college degree has a positive impact on physical abuse, while having only a high school diploma or some college does not. ${ }^{231}$ It is important to note, however, that her research also shows that education is not related to emotional abuse. ${ }^{232}$

The third and fourth areas documented by Christy-McMullin for economic security are employment and income. Not all employment leads to economic security. Rather, employment is integral to security when it provides a decent wage that raises the employee and her family above the poverty line at a minimum, and provides the employee with job flexibility, paid leave, and/or a chance for promotion. ${ }^{233}$ A broad range of longstanding barriers to such employment exist, such as discrimination against persons subjected to abuse, unequal pay between men and women, lack of a broad-scale living wage for minimum wage workers, and gender segregation relegating women into part-time employment with few or no benefits. ${ }^{234}$ Research also shows that employment is beneficial because physical abuse is less prevalent in households with higher income. ${ }^{235}$

The fifth area of economic security is assets. Studies show that assets such as ownership of a home, real property, or a small business are important aspects of a woman's perception of economic security. ${ }^{236}$ Studies by Deborah Page-Adams and Roger Peterson show that women who own their own homes are less likely to experience intimate partner abuse than women who rent. ${ }^{237}$ Moreover, when women controlled their assets like a home, even if it was rented, they were able to have more satisfying intimate relationships and decrease the rate of intimate partner abuse. ${ }^{238}$ Studies also show that there is a significant relationship between asset ownership and intimate partner abuse, and that the two are negatively correlated.

230. See 45 C.F.R. $\$ 261.33$ (2014); Christy-McMullin, Designing Policies, supra note 9 , at 112 .

231. See Kameri Christy-McMullin \& Marcia A. Shobe, The Role of Economic Resources and Human Capital with Woman Abuse, 6 J. POL'Y PrAc. 3, 17 (2007).

232. See id. at 18 (noting research is limited and that women's level of income may play large factor in issue as well).

233. See Christy-McMullin, Designing Policies, supra note 9, at 112-13.

234. See Conner, supra note 36, at 383-86.

235. See Christy-McMullin \& Shobe, supra note 231, at 17-18 (providing this conclusion, but with caveat that significant relationship may not exist if race, ethnicity, marital status, and age are accounted for).

236. See Christy-McMullin, Designing Policies, supra note 9, at 113-14.

237. See id. at 114. But see Christy-McMullin \& Shobe, supra note 231, at 18 (noting that, while their study supported this conclusion, it may be that femaleonly asset owners may be at higher risk of physical abuse because male perpetrators of abuse are not at risk of losing assets).

238. See Johnson, Home, supra note 15, at 16-17 (citing Clark et al., supra note 201 , at $385-88)$. 
Accordingly, women's ownership of assets is correlated with reduced abuse, whether the assets are homes, small businesses, savings accounts, retirement accounts, pensions, or other personal property. 239

The sixth area of economic security is family law support orders. Many, though not all, civil protective order laws permit the petitioners to request economic support for children and themselves, reimbursement for expenses incurred due to the violence, control over the home, support for the home, such as rent and utilities, and control over a car for transportation. ${ }^{240}$ Divorce and child custody orders also include support orders for children and spouses. However, the current family and domestic violence laws, as written and as applied, create obstacles to women's economic security. For instance, although laws may permit emergency and temporary custody and support orders, courts may not in fact schedule hearings in a timely manner. ${ }^{241}$ Moreover, although divorce laws often require the division and distribution of marital property in an equitable manner, such equitable distribution may not in fact consider the economic effects of domestic violence, including the effects of economic abuse such as sabotaging education and employment opportunities and the isolation that reduces access to employment networks and social support. ${ }^{242}$ Further, if the woman remains the primary caretaker, a 50/50 split of assets, coupled with child support, calculated pursuant to the guidelines, does not adequately compensate the woman for the burden that caretaking responsibilities place on the woman's finances and employment opportunities. ${ }^{243}$

\section{E. Supporting Relationship Security Enhances the Social Capital of Persons Subjected to Abuse}

Focusing on security reorients the framework for addressing domestic violence from the danger/haven false dichotomy to an understanding that the person subjected to abuse is someone who is at the center of a broad web of relationships, connections, and support, composed of intimate and familial relationships, community, employment, home and health; and this web contributes to necessary security. As discussed above, respect for a woman's agency and dignity, including support for the woman's connection to her community, is critical for a successful response to domestic violence. Connections to the community help to develop and sustain her resilience in addressing the intimate partner abuse in her life. Because abuse is systemic in nature, a person subjected to abuse will be more satisfied with her response to abuse if she can also employ a systemic response. $23-25$.

239. See Christy-McMullin, An Evidenced-Based Approach, supra note 213, at

240. See Klein \& Orloff, supra note 69, at 931-41, 990-1004. Clinic.

241. This has been the experience of the student attorneys in my Family Law

242. See, e.g., Mo. Code Ann., Fam. Law § 8-205 (West 2014).

243. See Christy-McMullin, Designing Policies, supra note 9, at 114. 
As seen above in Part II.A., the coercive tactics of abuse include tactics of isolation and economic abuse, which create greater dependence upon the abuser and can hamper the ability of a woman subjected to abuse to counter the detrimental financial and health effects of the abuse. Research has shown that for women experiencing intimate partner abuse, their connection to their community is critical for their physical and psychological well-being. ${ }^{244}$ The likelihood of future abuse diminishes with a stronger network of supportive community for the woman subjected to abuse. $^{245}$ Critically, though, the community will best serve the woman who has experienced intimate partner abuse if it is attuned to the woman's experience of abuse and her judgments regarding how to best respond to the abuse.

Research shows that community connections are critical to family success. For instance, Carol Stack conducted an early study of survival strategies in an urban African-American community. Stack found that "domestic functions are carried out for urban Blacks by clusters of kin who do not necessarily live together ...."246 Rather, "the basis of these units is the domestic cooperation of close adult females and the exchange of goods and services between male and female kin." ${ }^{247}$ The families observed by Stack consisted of kin and non-kin who made up a small, organized, and stable network of persons who "interact[ed] daily," "share[d] reciprocal obligations," and provided for the "domestic needs of children and assuring their survival."248 Stack's study showed the "adaptive strategies, resourcefulness, and resilience of urban families under conditions of perpetual poverty or the stability of their kin networks." 249 These networks also engaged in "swapping" of items such as "food stamps, rent money, a TV, hats, dice, a car, a nickel here, a cigarette there, food, milk, grits, and children." 250

The reality that parenting and families exist within a web of support has been shown to be vital to family success in current times as well. ${ }^{251}$

244. See Goodman \& Epstein, supra note 8, at 99.

245. See id. at 101.

246. Carol B. Stack, All Our Kin: Strategies for Survival in a Black ComMUNITY 9 (1974).

247. Id. (citing Carol Stack, The Kindred of Viola Jackson: Residence and Family Organization of an Urban Black American Family, in Afro-American Anthropology: Contemporary Perspectives (N.E. Whitten \& John F. Szwed eds., 1970)).

248. Id. at $30-31$.

249. Id. at 22.

250. Id. at 32 .

251. See Melissa Murray, The Networked Family: Reframing the Legal Understanding of Caregiving and Caregivers, 94 VA. L. REv. 385, 387 (2008) (discussing network of caregivers that help support and aid parents and family unit). See generally Clare Huntington, Failure to Flourish: How Law Undermines Family Relationships 14 (2014); Clare Huntington, Flourishing Families, 50 FAм. Ст. Rev. 273, 277-78 (2012) (arguing that family law should be more oriented toward establishing strong, stable, and positive relationships to prevent family crises and, in cases of family crises, intervene in order to preserve and repair relationships). 
Some options supporting the connection between women experiencing abuse and their community currently receive some federal funding. For instance, open shelters-shelters which are situated in a residential community and are known to be shelters by the community-permit women subjected to abuse to be in a neighborhood and be known by their neighbors. ${ }^{252}$ Other shelters are located in confidential locations. They do not identify their purpose to people and entities in their proximity. The women residents are not permitted to share the location of the shelter or invite their family, friends, lawyers, or other service providers from outside the shelter to the shelter. Moreover, confidential shelters may be located a great distance from the woman's actual neighborhood and community. ${ }^{253}$ Therefore, the shelter serves as an actual physical barrier between the woman and her support network and community. Research shows that open shelters are just as safe as confidential shelters because, although the location is known to the abusive person, the community acts vigilantly on behalf of the woman. ${ }^{254}$ She is not as isolated as she would be in the confidential shelter, and so her life satisfaction is increased. By focusing on security, we can develop and maintain other options to support the choice of the person subjected to abuse to remain connected with her community. For example, policies should respect a person's decision to avoid shelters and remain at her home in close proximity to her community support network of family, friends, and neighbors. This network could be critical to maintaining her employment, child care, and general support.

In addition, the development of a woman's social capital, "social relationships based on trust that have value or can be used productively," 255 can be instrumental in addressing domestic violence as well. ${ }^{256}$ While social capital is important for persons in all economic classes, ${ }^{257}$ it is essential for those experiencing poverty in order to access employment with a living wage. Moreover, persons subjected to abuse must build social capital across various institutions, communities, and individuals in order to rise from poverty and address persistent abuse. For welfare recipients, "social capital generated within closed networks of sharing relationships as well as bridging capital that crosses class, race, and social boundaries"

252. See Goodman \& Epstein, supra note 8, at 102.

253. See id. at 102, 121-22.

254. See Johnson, Home, supra note 15, at 38 (citing Goodman \& Epstein, supra note 8 , at 102).

255. Jo Anne Schneider, Social Capital and Welfare Reform: Organizations, Congregations, Communities 9 (2006). $366-69$.

256. See Goodman \& Epstein, supra note 8, at 101; Conner, supra note 36, at

257. See Robert D. Putnam, Bowling Alone: The Collapse and Revival of American Community 321 (2001). 
helps "to create relationships of trust" that are instrumental for accessing and maintaining critical resources. ${ }^{258}$

\section{Proposals Toward Security-The Legal and Funding Landscape}

In this Part, I set forth a variety of legal, funding, and policy proposals intended to promote women's security.

\section{A. Expand Actionable Harm in Civil Protection Order Laws}

Focusing on security requires institutions to identify all forms of abuse, including non-physical abuse and all forms of harm from the broad range of abuse. Civil protection order laws should be expanded to address all forms of abuse. Relief should be available to persons subjected to emotional, psychological, and economic abuse, in addition to physical abuse. Immigration law, divorce law, and public benefits law provide useful models, as each identifies domestic violence as physical and emotional cruelty. ${ }^{259}$ By expanding the forms of abuse that are actionable, the law will address the actual experience of petitioners who have been subjected to abuse and create further options for them to seek a court-ordered remedy to address the abuse.

\section{B. End Mandatory Responses}

To effectuate security, jurisdictions should end all mandatory responses to domestic violence, such as laws and policies that mandate arrest, "no-drop" prosecution policies, and criminal no contact orders against the will of the person subjected to abuse. As discussed above, the research shows that women subjected to abuse are the best predictors of their risk of future abuse. ${ }^{260}$ In addition, when women subjected to abuse are able to make their own decisions about how to respond to the abuse, they are more satisfied with the results-and the violence to which they are subjected tends to decrease. ${ }^{261}$

\section{Address Barriers to Employment}

Economic security can be promoted for persons subjected to intimate partner abuse by legislation that addresses barriers to employment and provides exceptions to unemployment insurance for persons subjected to abuse. These laws need to define domestic violence broadly to include the full range of abuse, giving women subjected to abuse full access to economic security. As discussed above, economic abuse can include sabotaging one's employment through a variety of tactics, such as constraining the

258. Michele Estrin Gilman, Jo Anne Schneider' Social Capital and Welfare Reform: Organizations, Congregations, and Communities, 32 J. Urb. AfF. 511, 511 (2010) (book review).

259. See Johnson, Redefining Harm, supra note 5, at 1156-61.

260. See supra notes 188-204 and accompanying text.

261. See id. 
employee's ability to leave for work in a timely fashion, sabotaging one's transportation to and from work, showing up at one's place of work, and contacting the employee at work to render her unable or seemingly unable to perform her duties. Moreover, the person subjected to abuse may need to take leave in order to address the domestic violence, for matters such as criminal or civil litigation that require multiple court appearances. Similarly, up to one half of persons subjected to abuse report that they lost their employment due to the abuse. ${ }^{262}$ Accordingly, legislation protecting the employment of persons subjected to abuse is necessary.

Some states have passed such legislation, but all states need to do so. As of 2013, fifteen states and the District of Columbia had laws in place to protect employment rights of persons subjected to abuse. ${ }^{263}$ Nine states prohibit discrimination or retaliation against an employee who was subjected to domestic violence either because she was a subjected to abuse, because there was disruption at the workplace related to the abuse, or because she took time off from work to address the domestic violence. ${ }^{264}$ Three states have laws requiring the employer to offer workplace accommodations to the employee because of the abuse, such as relocation, flexible work schedule, and screening of incoming telephone calls. ${ }^{265}$ Further, ten states and the District of Columbia require employers to offer some form of leave to employees subjected to abuse when necessary to address the abuse, such as preparing to participate in court proceedings, to receive medical treatment or counseling, to obtain safety planning resources, and to secure housing assistance, relocation assistance, and legal assistance. ${ }^{266}$ The states vary on the amount of leave, whether it is paid or unpaid, and on the types of actions that will be eligible for the leave. ${ }^{267}$ Economic security would be greatly increased if each jurisdiction passed similar legislation recognizing the employment rights of persons subjected to abuse.

262. See Julie Goldscheid \& Robin Runge, Employment Law and Domestic Violence: A Practitioner's Guide 3 (2009), available at http://www.americanbar .org/content/dam/aba/migrated/domesticviolence/PublicDocuments/ABA_ CDV_Employ.authcheckdam.pdf ("Up to half of employed victims of domestic violence report that they lost their jobs due at least in part to the domestic violence ....").

263. See Legal Momentum, State Law Guide-Employment Rights for Victims of Domestic or Sexual Violence (Aug. 13, 2013), available at http://www .scribd.com/doc/160011402/State-Law-Guide-Employment-Rights-for-Victims-ofDomestic-or-Sexual-Violence.

264. See id. at 1-9 (noting, as of 2013, states with some form of such legislation are California, Connecticut, Hawaii, Illinois, Kansas, New York, North Carolina, Oregon, and Rhode Island).

265. See id. (showing Hawaii, Illinois, and Oregon have some such form of legislation).

266. See id. (noting states with some form of such legislation are Colorado, Connecticut, District of Columbia, Florida, Georgia, Hawaii, Illinois, Maine, New Mexico, Oregon, and Washington).

267. See id. 
In addition, federal legislation in the area of employment rights for persons subjected to abuse needs to be passed. ${ }^{268}$ There have been major legislative initiatives that have been introduced in Congress, but as of yet, not passed. For instance, Congress proposed the Security and Financial Empowerment Act, which provides for workplace emergency leave, antidiscrimination provisions, and reasonable accommodation provisions for persons subjected to abuse. ${ }^{269}$ Congress also proposed the Healthy Families Act, which provides for paid sick leave that can be used by persons subjected to domestic abuse to pursue legal action and to obtain medical attention, services, counseling, and relocation. ${ }^{270}$ In addition, the Healthy Families Act precludes retaliation against the employee for taking such leave. ${ }^{271}$ Such federal legislation needs to be passed to ensure economic security.

To assist persons subjected to abuse in finding employment, programs should be offered that provide effective career counseling for such persons. One effective model of career counseling is based upon an empowerment model and is called Social Cognitive Career Theory (SCCT). ${ }^{272}$ SCCT requires career counselors to "facilitate critical reflection and awareness of the power dynamics at work in battered women's lives; facilitate the recognition, enhancement, and use of the skills and resources these women have; and, ultimately, facilitate the ability of these women to contribute to the empowerment of others." 273 This model uses Ellen Harley McWhirter's empowerment theory, which defines empowerment as:

"[T] he process by which people, organizations, or groups who are powerless or marginalized (a) become aware of the power dynamics at work in their life context, (b) develop the skills and capacity for gaining some reasonable control over their lives, (c) which they exercise, (d) without infringing on the rights of others, and (e) which coincides with actively supporting the empowerment of others in their community." 274

268. For a discussion of proposed federal legislation as well as other legal responses to employment needs of persons subjected to abuse, see Robin R. Runge, The Legal Response to the Employment Needs of Domestic Violence Victims: An Update, 37 Hum. Rтs. 13 (2010); see also Deborah A. Widiss, Domestic Violence and the Workplace: The Explosion of State Legislation and the Need for a Comprehensive Strategy, 35

FlA. ST. U. L. REv. 669, 674 (2008) (discussing trends in domestic violence laws).

269. See Legal Momentum, supra note 263, at 14 (citing H.R. 1229, 113th Cong. (2013)).

270. See id. at 14-15 (citing H.R. 1286/S. 631, 113th Cong. (2013)).

271. See id. at 15 .

272. See Krista M. Chronister \& Ellen Hawley McWhirter, Applying Social Cognitive Career Theory to the Empowerment of Battered Women, 81 J. Counseling \& Dev. 418, 422 (2003).

273. $I d$.

274. Id. (quoting Ellen Harley McWhirter, Counseling for Empowerment $12(1994))$. 
Accordingly, SCCT uses the "five Cs of empowerment," 275 which include: collaboration, ${ }^{276}$ context, ${ }^{277}$ competence, ${ }^{278}$ critical consciousness, ${ }^{279}$ and community, ${ }^{280}$ in order to effectively assist women subjected to abuse in identifying and obtaining their career goals.

\section{Expand Eligibility for Unemployment Insurance Benefits}

Reformers can promote the economic security of persons subjected to abuse who lose their employment due to abuse by expanding eligibility for unemployment insurance. ${ }^{281}$ At present, individuals cannot qualify for unemployment insurance when they leave their job voluntarily, unless they have "good cause" for leaving. ${ }^{282}$ In many states, personal reasons do

275. Id. ("Recommendations for empowering battered women and for developing interventions that address the variables and relationships defined by SCCT are aligned with the five Cs of empowerment: collaboration, context, competence, critical consciousness, and community.").

276. See id. Collaboration is essential for effective career counseling because it frames the process as the "mutual definition of the problems and construction of goals as well as collaborative and flexible strategies for change." Id. As such, the person subjected to abuse is identified as central to the counseling as it is her life and goals at issue, while the counselor has an integral role in facilitating the counseling. See id.

277. See id. To be effective in the counseling, assumptions or generalizations cannot guide the process. Rather, it is "essential that the battered woman's life situation, including her educational and career concerns, be understood in context." Id. Specifically, effective career counseling needs to account for her culture; family structure; religious, community, economic and support network; law enforcement sensitivity; and local opportunities for employment and school. Id.

278. See id. Chronister and McWhirter explain that effective career counseling requires the counselor and the woman to recognize "the skills, resources, and experiences that women possess and that may contribute to achieving their counseling goals as well as to developing new skills." Id. (citation omitted).

279. See id. Critical consciousness emphasizes the individual's ability to examine herself within her life context and her ability. See id. Specifically, this component engages a power analysis for the woman to identify how she is and can be transforming the identified power operating. See id. It also serves to identify support for the woman in her community as well as obstacles. The career counselor also needs to engage in this reflection to ensure that her privilege does not undermine the woman's work. Id. at 423.

280. See id. Community serves many goals for career counseling. Community can be created through support groups or facilitated through similar interests or existing connections. This community can then "provide validation of roles and identity; physical, emotional, and social support; and opportunities for belonging and contribution." Id. In addition, the community can serve as a network for school and job opportunities, development of specific skills, and development of general skills required to be persuasive and equipped in oral advocacy. See id.

281. See generally Runge, supra note 268 (noting some states have amended unemployment insurance statutes to include or exclude persons subjected to domestic violence).

282. See Nat'l Emp't L. Project, Unemployment Insurance for Survivors of Domestic Violence: Expanding UI for Women, Low-Wage \& Part-Time WorkERS 2 (2003), available at http://nelp.3cdn.net/8ffcd6de3f649a187f_b2m6bn78c .pdf. 
not qualify as good cause. ${ }^{283}$ Some states have established a replicable model, in which experiencing domestic violence can qualify as "good cause" for leaving employment. ${ }^{284}$ Other states have recognized that people who experience domestic violence may be unable to satisfy a requirement of being "able and available" to work. ${ }^{285}$ More than thirty jurisdictions have passed laws that explicitly include domestic violence within the definition of "good cause" or otherwise provide unemployment insurance to domestic violence survivors. ${ }^{286}$ While the details of each law vary, in most cases, the applicant must fulfill all other eligibility requirements for unemployment insurance, and often the applicant must provide documentation or certification of the violence. ${ }^{287}$ In addition, under the American Recovery and Reinvestment Act of 2009 and the Worker, Homeownership, and Business Assistance Act of 2009, grants were provided to the states to extend unemployment insurance benefits to workers who leave their jobs due to domestic violence, but those extended benefits ended in the beginning of 2014. ${ }^{288}$

\section{See id.}

284. See id.

285. See id.

286. Legal Momentum, State Law Guide: Unemployment Insurance Benefits for Domestic \& Sexual Violence Survivors (June 2013), available at http:// www.legalmomentum.org/sites/default/files/reports/State\%20Guide\%20UI\%20 Final\%20June\%202013.pdf (providing state-by-state analysis for all 50 states and District of Columbia).

287. See id. For additional resources concerning domestic violence and unemployment insurance, see Legal Momentum, ARRA: Extending the Unemployment Insurance Safety Net to Victims of Domestic Violence (Oct. 2009), available at http://www.ncdsv.org/images/LegalMom_ARRA\%20and\%20UI.DV_ 10-09.pdf; Legal Momentum, Tips for Domestic Violence Victims Seeking UnemPLOYMENT INSURANCE (2006), available at http://www.legalmomentum.org/sites/ default/files/reports/uitipsletterhead.pdf; Domestic Violence, Sexual Assault E् Stalking: Unemployment Insurance If You Must Quit, Legal Aid Society Emp'т L. CтR., https://las-elc.org/fact-sheets/domestic-violence-sexual-assault-stalking-unemployment-insurance-if-you-must-quit (last visited Jan. 22, 2015); Information Sheet: Services for Victims of Domestic Violence Abuse, Emp't Dev. Dep't., State of Cal. (July 2014), http://www.edd.ca.gov/pdf_pub_ctr/de8323.pdf; The Need to Leave Work: Your Rights as a Domestic Violence Survivor, MassLegalHelp (Dec. 2012), http:/ /www .masslegalhelp.org/employment-unemployment/domestic-violence-time-off; Unemployment Benefits for Domestic Violence Survivors: What Are Its Costs?, NaT'L EMP. L. Project (2005), http://www.nelp.org/page/-/UI/dvuicost2005.pdf; see also L'Nayim A. Shuman-Austin, Comment, Is Leaving Work to Obtain Safety "Good Cause" to Leave Employment? - Providing Unemployment Insurance to Victims of Domestic Violence in Washington State, 23 Seattle U. L. Rev. 797, 827 (2000).

288. See Runge, supra note 268; see also American Recovery and Reinvestment Act of 2009, Pub. L. No. 111-5, § 2003 (f) (3) (B) (i), 123 Stat. 115, 440-441 (codified at 42 U.S.C. $\S 1103$ (f) (3) (B) (i) (2012)); Worker, Homeownership, and Business Assistance Act of 2009, Pub. L. No. 111-92, § 7, 123 Stat. 2984; 26 U.S.C. $\S 3004$ note (2012), amended by American Taxpayer Relief Act of 2012, Pub. L. No. 112-240, § 501, 126 Stat. 2313, 2344 (extending grants provided in American Recovery and Reinvestment Act of 2009 and Worker, Homeownership, and Business Assistance Act of 2009 that maintained unemployment benefits for persons subjected to abuse until January 1, 2014). 


\section{E. Increase Access to Public Benefits}

Another way to increase income for women subjected to abuse is by increasing their access to public benefits if they are income eligible. ${ }^{289}$ For instance, the TANF ${ }^{290}$ program provisions that permit persons subjected to abuse to obtain TANF without increasing their risk of abuse should be available to persons subjected to all forms of abuse, not simply physical abuse. Ordinarily, TANF has strict requirements for eligibility: the individual must be employed and must be seeking child support where applicable. ${ }^{291}$ Additionally, TANF has a five-year (or sixty-month) limit, meaning that an individual may not receive TANF for more than sixty months (whether consecutive or non-consecutive) total in her life. ${ }^{292}$ But because domestic violence could increase if the TANF applicant were to seek child support from her abuser, or if she reported to her worksite, Congress passed the Family Violence Option (FVO), wherein the states are allowed to waive any of the TANF requirements for persons subjected to abuse. $^{293}$ By adopting the FVO, a state certifies that it will screen to identify persons subjected to abuse while maintaining their confidentiality; will refer them to supportive services; and will waive program requirements such as time limits on the receipt of benefits, work requirements, or cooperation with child support enforcement if those requirements make it more difficult to escape the violence or would unfairly penalize the person. ${ }^{294}$ Notably, "[a]ll states have either formally certified adoption of the FVO [forty-one states and the District of Columbia] or reported to the federal government adoption of a comparable policy."295 Additionally, states are allowed to exempt $20 \%$ of their TANF caseload from the sixtymonth time limit for cases of "hardship," including women who have been

289. Cf. Richard C. Fording \& William D. Berry, The Historical Impact of Welfare Programs on Poverty: Evidence from the American States, 35 Pol. STud. J. 37, 37 (2007) ("Many analysts have maintained that public assistance expansion during this period decreased poverty by raising the incomes of the poor (an income enhancement effect), while others have contended that welfare expansion increased poverty by discouraging the poor from working (a work disincentive effect).").

290. TANF was established through the Personal Responsibility and Work Opportunity Reconciliation Act of 1996 (PRWORA). See Nat'l L. Ctr. on Homelessness \& Poverty, Shortchanging Survivors: The Family Violence Option for TANF BeNEFits 4 (Dec. 2009), available at http://www.ncdsv.org/images/NLCHP_ ShortchangingSurvivorsTheFVOptionForTANFbeneftis_12-2009.pdf [hereinafter Shortchanging Survivors].

291. See id. at 13.

292. See id.

293. See id. at 13-14; U.S. Dep't of Health \& Hum. Servs., Office of Family Assistance, TANF Final Rule Executive Summary (Apr. 12, 1999), available at http://www.acf.hhs.gov/programs/ofa/resource/tanf-final-rule-executive-summa ry.

294. See Timothy Casey et al., Legal Momentum \& Nat'l Res. Ctr. on Domestic Violence, Not Enough: What TANF Offers Family Violence Victims 2 (Mar. 2010), available at http://www.legalmomentum.org/assets/pdfs/notenough-what-tanf-offers.pdf.

295. Id. 
battered or subjected to extreme cruelty. ${ }^{296}$ Unfortunately, despite the fact that the TANF waiver defines domestic violence broadly as "battered or subjected to extreme cruelty," ${ }^{297}$ TANF case workers interpret domestic violence as physical violence, thus limiting who can gain access to the TANF economic and other resources. ${ }^{298}$ For instance, in New York State, waivers of TANF requirements are granted only where applicants can show that they are currently in danger. ${ }^{299}$ This excludes persons who are subjected to nonphysical abuse or who may not be in current danger because the person committing the acts of abuse is incarcerated, for example. Persons subjected to abuse are also denied the waiver if they are unable to comply with the monthly reevaluation requirement to remain qualified for the FVO because of the other demands on their time from addressing the intimate partner abuse. ${ }^{300}$ TANF has been shrinking and its effectiveness in lifting persons out of poverty and providing economic security has decreased despite calls from advocates who recommend that TANF benefits be increased. ${ }^{301}$

Additional provisions should be passed so that persons subjected to abuse may access public benefits. The EITC is the largest and most effective public assistance benefit available. ${ }^{302}$ Currently, under the EITC, mar-

296. See Rachel J. Gallagher, Welfare Reform's Inadequate Implementation of the Family Violence Option: Exploring the Dual Oppression of Poor Domestic Violence Victims, 19 Am. U. J. Gender Soc. Pol'y \& L. 987, 1000-01 (2011); see also Casey et. AL., supra note 294.

297. 42 U.S.C. $§ 608(a)(7)$ (C) (iii) (2012). The definition of "battered or subjected to extreme cruelty" is:

(I) physical acts that resulted in, or threatened to result in, physical in-

jury to the individual;

(II) sexual abuse;

(III) sexual activity involving a dependent child;

(IV) being forced as the caretaker relative of a dependent child to en-

gage in nonconsensual sexual acts or activities;

(V) threats of, or attempts at, physical or sexual abuse;

(VI) mental abuse; or

Id.

(VII) neglect or deprivation of medical care.

298. See CASEy ET AL., supra note 294, at 11-12; Gallagher, supra note 296, at 1002 ("There is, however, substantial evidence that TANF case workers often fail to effectively screen for domestic violence and/or to offer waivers and service referrals when appropriate."); Shortchanging Survivors, supra note 290, at 17 (describing screening process); see also Shelly Kintzel, Comment, The Effects of Domestic Violence on Welfare Reform: An Assessment of the Personal Responsibility and Work Opportunity Reconciliation Act as Applied to Battered Women, 50 U. Kan. L. Rev. 591, 592-94 (2002) (discussing how domestic violence cannot be limited to physical abuse).

299. See Shortchanging Survivors, supra note 290, at 6-7.

300. See CASEy ET AL., supra note 294, at 12.

301. See id. at 16 .

302. For additional tax resources for survivors of domestic violence, see generally Nat'l Taxpayer Advocate, 2011 Annual Report to Congress 323 (Dec. 31, 2011), available at http://www.taxpayeradvocate.irs.gov/userfiles/file/TAS_arc 2011_execsummary.pdf; Nat'l Women's L. CTR., Tax Issues for Domestic Vio- 
ried couples who have lived together for at least six months of the last taxable year must sign a joint return in order to be eligible for the EITC. ${ }^{303}$ They cannot access the credit if they file "married filing separately" (MFS). ${ }^{304}$ Accordingly, the EITC would be unavailable in a situation in which the person subjected to abuse is married and living with her spouse but wishes to file separately to avoid further or future economic abuse or coercion. The EITC requirements should be modified to permit the MFS status to receive the EITC benefit under these circumstances.

There are a few ways in which this could be accomplished. ${ }^{305}$ First, as it did for a credit under the Affordable Care Act (ACA), the IRS could issue a Notice to permit the EITC to be available to persons subjected to abuse who are unable or unwilling to file jointly because of the abuse. ${ }^{306}$ Under the ACA Notice, a married taxpayer may file MFS if she is living apart at the time she files her tax return, she cannot file jointly because of the abuse, and she describes the situation in her tax return. ${ }^{307}$ A similar Notice could be issued for the EITC. Further, towards more security, the credit could be available even if the person subjected to abuse does not live separate and apart from her spouse who is abusive. One proposal for this is to permit her to file MFS and indicate that she is filing separately due to the abuse, is economically independent of her spouse, and requests an independent credit. ${ }^{308}$ Another option is to permit her to file MFS because of the abuse and then require the IRS to calculate the amount of the credit based on each spouse's separate filings, with the refund being split between the spouses.

Lence Survivors: What Advocates Need To Know (2007), available at http:// www.nwlc.org/sites/default/files/pdfs/tax_issues_for_dv_survivors.pdf; Earned Income Tax Credit: A Vital Financial Tool for Survivors of Domestic Violence, U.S. DeP'т of Health \& Human Serv., Family \& Youth Serv. Bureau (Mar. 1, 2013), http:// www.acf.hhs.gov/programs/fysb/news/earned-income-20130301; Your Money Matters: Tax Information for Survivors of Domestic Abuse, IRS (May 2014), http://www.irs .gov/pub/irs-pdf/p3865.pdf.

303. See Susan Morgenstern \& Mary M. Gillum, Consumer Rts. for Domestic Violence Survivors Initiative, Federal Tax Advocacy for Domestic VioLENCE Survivors 5 (2009), available at http://www.nclc.org/images/pdf/domestic _violence/intersection-tax-law02-24-2010.pdf. There is an exception if one's spouse did not live in the home for the last six months of the year. See IRS, PubliCATION 596: EARNED INCOME CREDIT 5 (2014), available at http:/ / www.irs.gov/pub/ irs-pdf/p596.pdf. If the spouse has not lived with the other spouse for six months in the year, she may be able to file as head of household instead. See id.

304. See IRS, supra note 302, at 5.

305. Thanks to Fred Brown and Leslie Book for thinking through this problem with me and providing sound suggestions.

306. See Leslie Book, ACA and Victims of Domestic Abuse, Procedurally Taxing (Apr. 3, 2014), www.procedurallytaxing.com/aca-and-victims-of-domestic-abuse/.

307. See id.

308. Thanks to Fred Brown for this idea, which I have simplified for purposes of this discussion. 


\section{F. Block Coerced Debt from Credit Reporting Agencies}

As discussed in Part III above, access to assets is critical for security because such access has a negative correlation to intimate partner abuse. Accordingly, proposals that enhance the assets of a person subjected to abuse will increase the likelihood of reduced exposure to future violence. One way to increase assets is to increase one's credit rating or address negative credit ratings. As Angela Littwin has documented, financial abuse can be perpetrated by "coerced debt," defined as "nonconsensual, credit-related transactions . . ."309 Debt can be coerced in multiple ways, including taking credit cards out in a partner's name, forcing a partner to take loans, tricking a partner into signing a quitclaim deed to a home, and excessively charging a partner's credit cards. ${ }^{310}$ Coerced debt can destroy a person's credit rating, ${ }^{311}$ which, in turn, can limit the ability to rent an apartment or take out a car loan, and can increase the interest rate on a loan. ${ }^{312}$ By creating obstacles to obtaining housing, coerced debt impinges on the security of a person subjected to abuse. ${ }^{313}$ Littwin proposes blocking coerced debt from credit reporting agencies and having family courts decide the parties' responsibility for coerced debt. ${ }^{314}$ Littwin's proposal provides an initial step towards addressing the security of persons subjected to abuse. To further address these issues, community-based educational programs could be funded to address economic abuse and coerced debt, as well as various other ways to address them.

\section{G. Allow Monetary Damages in Civil Protection Order Cases}

All United States jurisdictions could include monetary damages in their CPO laws for injuries to persons subjected to abuse, whether they be physical, sexual, emotional, psychological, or economic. ${ }^{315}$ Only twentytwo jurisdictions specifically permit restitution as a form of relief from domestic violence. ${ }^{316}$ Compensatory damages are another area that should

309. Angela Littwin, Coerced Debt: The Role of Consumer Credit in Domestic Violence, 100 CAL. L. REv. 951, 954 (2012).

310. See id. at 986-91. Misuse of one's partner's social security number to take out loans or credit cards in that person's name is another form of coerced debt. See id. at 987 . Fortunately, a person subjected to abuse may request a new social security number if they are being harassed, abused, or if their life is in danger. See Soc. Sec. Admin., New Numbers for Domestic Violence Victims (Sept. 2013), available at http://www.ssa.gov/pubs/EN-05-10093.pdf. This provision is a good example of a security provision, as it defines domestic violence broadly to include all forms of abuse.

311. See Littwin, supra note 309, at 1000-03.

312. See id. at 992-93, 1002.

313. See id. at 1002-03 (noting coerced debt often prevents women from leaving abusive relationships).

314. See Angela Littwin, Escaping Battered Credit: A Proposal for Repairing Credit Reports Damaged by Domestic Violence, 161 U. PA. L. Rev. 363, 390-408 (2013).

315. See Johnson, Redefining Harm, supra note 5, at 1155.

316. See ABA Comm'n on Domestic Violence, supra note 151 (noting states with CPO remedy of restitution are Alaska, California, Connecticut, Delaware, Illi- 
be expanded in CPO laws. One effective approach to granting this remedy is seen in those jurisdictions that permit " any other relief that would address the domestic violence'...."317 Such a "catch-all" remedy permits persons subjected to abuse to identify how they have been harmed by the abuse and to seek a remedy for their injuries. ${ }^{318}$ While forty jurisdictions in the United States include a catch-all remedy in their CPO laws, they are rarely, if ever, used for compensatory damages and full restitution. To ensure security for persons subjected to abuse, all jurisdictions should both include a robust catch-all remedy in their CPO laws and use them to award compensatory damages.

\section{H. Increase Housing Options ${ }^{319}$}

Further, all civil protective order laws should create viable short- and long-term housing remedies that provide shelter and are sustained by government subsidy or by shifting the cost of the housing to the person who perpetrated the abuse. ${ }^{320}$ Similarly, all jurisdictions should pass laws that permit renters subjected to intimate partner abuse to maintain secure housing options by evicting the person perpetrating the abuse, terminating her lease early if she wants to leave the shared rented home, and changing the locks of a rented apartment. ${ }^{321}$

To increase housing security, certain steps could be taken. First, as discussed above, government money allocated to less effective safety paradigm responses to domestic violence could be shifted to fund security paradigm options, such as low-barrier open shelters that have few treatment or other requirements to maintain residency, transitional housing, and long-term housing. ${ }^{322} \mathrm{CPO}$ laws should not only allow the petitioner to exclude the person committing the abuse, they should also allow the petitioner to request that the respondent contribute to alternative housing for the person subjected to abuse if she chooses to leave the home. ${ }^{323}$ Jurisdictions could also provide rental assistance for an extended period of time to support a person subjected to abuse who lives in alternative hous-

nois, Indiana, Maine, Massachusetts, Minnesota, Mississippi, Missouri, Montana (though it is unclear), Nevada, New Hampshire, New Jersey, New Mexico, New York, Oregon (limited to emergency monetary award), Pennsylvania, Tennessee, West Virginia, Wyoming (only medical)).

317. See Johnson, Redefining Harm, supra note 5, at 1155 (quoting Klein \& Orloff, supra note 69 , at $912-14$ ).

318. See id.

319. See generally Johnson, Home, supra note 15, at 17-46 (providing full discussion of housing options in context of domestic abuse).

320. See id. at 26.

321. See id. at 18-26.

322. See id. at 50-51.

323. See id. at 53 (discussing CPO laws in New Jersey and West Virginia that permit petitioners to obtain funds for alternative housing from respondents, as well as CPO laws in ten jurisdictions requiring respondents to provide alternative housing to petitioners). 
ing. ${ }^{324}$ If, on the other hand, the CPO petitioner is able to vacate the respondent from the home, CPO laws should afford petitioners the ability to obtain a share of the household maintenance expenses from the respondent to ensure that she can maintain the home. ${ }^{325}$ All jurisdictions should have laws that permit persons subjected to abuse to terminate their leases early if necessary to address the violence. ${ }^{326}$ Also, all jurisdictions should have laws that prohibit discrimination in housing, rental or owned, against persons subjected to abuse. ${ }^{327}$ Such laws will permit persons to access and maintain stable housing. All jurisdictions should have laws that permit the person subjected to abuse to defend against a landlord's eviction action based on the domestic violence. ${ }^{328}$ Further, all jurisdictions should have laws that permit renters subjected to abuse to require their landlords to change the locks to protect against future domestic violence. ${ }^{329}$ Finally, all jurisdictions should permit a petitioner to seek a CPO injunction against future abuse without requiring she stay away from or not contact the respondent. ${ }^{330}$ When the person subjected to abuse chooses to stay in the relationship that had been abusive, her decision should be respected and accepted, to enhance her relationship, health, and, here, her housing security.

\section{Time Banking}

Another way to increase the relationship security of a person subjected to abuse is to create or recreate her connection to the community and build her social capital. One way to effectively build social capital and connect a person subjected to abuse to her community is Time Banking

324. See id. (citing Alaska's law providing rental assistance for thirty-six months).

325. See id. at 26 (discussing CPO vacate provisions in New Jersey and Missouri that require respondent to pay portion of rent or mortgage if excluded from home).

326. Id. at $33 \mathrm{n} .141$ (citing rental laws in Arizona, Colorado, Delaware, Washington, D.C., Illinois, Indiana, Maryland, Minnesota, New York, North Carolina, Oregon, Texas, Washington, and Wisconsin that permit persons subjected to abuse to terminate their leases early).

327. See id. at 37 n.153 (citing anti-discrimination laws in Washington, D.C., Indiana, North Carolina, Oregon, Rhode Island, Washington, Wisconsin, and Westchester County, New York that prohibit housing discrimination against persons subjected to abuse).

328. See id. at 19-20. Currently, only eleven jurisdictions have laws protecting persons subjected to abuse from this variety of landlord action. See id. at 20 n.81 (noting Colorado, District of Columbia, Iowa, Louisiana, Maryland, Minnesota, New Mexico, Oregon, Virginia, Washington, and Wisconsin have such laws).

329. See id. at 19-20. Currently, only ten states have laws that allow tenants to change the locks on their apartments because of abuse. See id. at 20 n.88 (noting that Arizona, Arkansas, Illinois, Indiana, Maryland, North Carolina, Oregon, Utah, Virginia, Washington, and Washington, D.C. currently have laws to this effect).

330. See id. at 45 (citing Maryland's law allowing petitioner to seek injunction against future abuse without also requiring abuser to leave home or stop contacting petitioner). 
and Co-Production. ${ }^{331}$ Time Banking is an economy that relies on people's work and giving time rather than money. It is being used in over twenty countries to meet people's needs and deal with social problemssuch as childcare, mental illness, job training, social justice movements, transportation, and drug treatment. ${ }^{332}$ Unlike the monetary economy, as Professor Edgar Cahn explains, the invisible core economy that Time Banking relies upon is made up of "family, neighborhood, community, and civil society." 333

Time Banking uses human resources, where a person can give an hour to someone else to perform such assistance as caring for a child or tutoring someone, and that hour spent also creates a relationship. As Cahn explains, "[w] hen we give an hour to rebuild community, we are building something we cannot buy. Time Banking enables us to value that and in doing so, we value ourselves, our time, our being." ${ }^{334}$ When a person gives an hour to another, the person earns one Time Dollar. ${ }^{335}$ The person who is helped owes one Time Dollar and can pay it by helping anyone. ${ }^{336}$ There is a database that identifies what persons in the community are able and willing to do and when they can do it. ${ }^{337}$ A need for assistance is matched using the database. ${ }^{338}$ This same system keeps track of what a person is owed or has earned. ${ }^{339}$

Time Banking is beneficial not just because it provides the person subjected to abuse with assistance but also because its reciprocal nature allows her to feel as though she is connected and contributing to her community. Research shows that acting more like friends is a healing and restorative venture. ${ }^{340}$ Co-Production is a construct that helps explain the value and mechanics of Time Banking and the shared social justice goals of respecting human beings. ${ }^{341}$

According to Cahn, social capital, "composed of trust, reciprocity, and civic engagement," is generated through Time Banking and Co-Produc-

331. See generally Edgar S. Cahn, Priceless Money: Banking Time for Changing Times (2006) [hereinafter Cahn, Priceless Money]; Edgar S. Cahn, No More Throw-Away People: The Co-Production Imperative (2d ed. 2004) [hereinafter Cahn, No More Throw-Away People]; Edgar Cahn \& Jonathan Rowe, Time Dollars: The New Gurrency that Enables Americans to Turn their Hidden Resource-Time-into Personal Security \& Community Renewal (1992) [hereinafter, Cahn \& Rowe, Time Dollars].

332. See Cahn, Priceless Money, supra note 331, at 6. See generally Cahn, No More Throw-Away People, supra note 331; Cahn \& Rowe, Time Dollars, supra note 331 .

333. See Cahn, Priceless Money, supra note 331, at 1.

334. Id. at 4.

335. See id. at 5 .

336. See id.

337. See id.

338. See id.

339. See id.

340. See Cahn \& Rowe, Time Dollars, supra note 331, at 86-87, 89-90.

341. See Cahn, No More Throw-Away People, supra note 331, at 29, 31. 
tion. ${ }^{342}$ These mechanisms could be a useful vehicle for persons subjected to abuse who want to be connected to their community and also have needs that their neighbors could help fulfill. ${ }^{343}$ In return, the person subjected to abuse would also help others, in order to earn Time Dollars for those owed. The benefits would be the ability to address child care, job training, and health care needs without money; identifying one's own capacity and abilities; feeling empowered by helping another and making a difference; and gaining friends and a stronger, larger network. Moreover, Time Banking is built around the idea that all people are agents and have vast capabilities. They are not problems or victims, but rather solutions. ${ }^{344}$ People are not in need of charity or a hand out, but rather can make their own change. Such ideas are integral to a security paradigm as well, making Time Banking a useful model for expanding security options. ${ }^{345}$

\section{J. Increase Utilization of Tort Law}

Tort law is an underutilized potential vehicle for recovery of economic damages for people subjected to abuse. People subjected to threatened or actual physical violence may recover damages for battery and assault. ${ }^{346}$ A claim of intentional infliction of emotional distress ${ }^{347}$ may provide damages for emotional distress resulting from "extreme and outrageous conduct." 348 In addition to common law tort claims, several states and municipalities have laws that are specific to domestic and gender-based violence. For instance, in New Jersey and Washington, the "battered women's syndrome" tort allows consideration of a pattern of coercive behavior that constitutes intimate partner abuse. ${ }^{349}$ In New York City, a woman subjected to abuse can file a claim based upon a gender-

342. Id. at 169.

343. Similar to the ideas of Time Banking and Co-Production, Carol Stack studied and then documented how Urban Blacks in the 1960s survived despite limited economic resources. See supra notes 246-50 and accompanying text.

344. See Edgar Cahn, Audrey Jordan, Elvira Méndez \& Sharon Lee Schwartz, Human Rights and Time Banking, http://timebanks.org/wp-content/uploads/ 2011/08/Human-Rights-and-TimeBanking.pdf (last visited Jan. 23, 2015).

345. Time Banking has been used by a project working with 5,000 women, as discussed by Elvira Méndez and her co-authors. See id. at 2. If the project's screening showed domestic violence, then a group of men and women worked together to respond to the situation in a supportive group environment focused on empowerment. See id.

346. See Camille Carey, Domestic Violence Torts: Righting a Civil Wrong, 62 U. Kan. L. Rev. 695, 696 (2014); see also Sarah M. Buel, Access to Meaningful Remedy: Overcoming Doctrinal Obstacles in Tort Litigation Against Domestic Violence Offenders, 83 Or. L. Rev. 945, 945 (2004); Jennifer Wriggins, Domestic Violence Torts, 75 S. Cal. L. Rev. 121, 133 (2001).

347. See Carey, supra note 346, at 696, 702-03 (discussing intentional infliction of emotional distress).

348. Restatement (Third) of Torts: Liability for Physical and Emotional Harm § 46 (2011); see also Johnson, Redefining Harm, supra note 5, at 1158.

349. See Carey, supra note 346, at 709-12. 
based crime committed against her, while in Illinois and California, women can bring a tort action for gender-based violence. This tort is based on an actual or threatened battery or sexual assault. ${ }^{350}$ In addition, California law recognizes a domestic violence tort that defines abuse as "intentionally or recklessly causing or attempting to cause bodily injury, or placing another person in reasonable apprehension of imminent serious bodily injury to himself or herself, or another." 351

Thus, tort law provides a mechanism through which a woman subjected to abuse may receive monetary damages for emotional and physical harm resulting from physical abuse and may do so without engaging the criminal justice system. ${ }^{352}$ Like criminal law, however, most cognizable tort law claims prioritize physical violence, ${ }^{353}$ failing to provide a remedy for other forms of abuse, such as emotional or economic abuse. ${ }^{354}$ Expanding tort law remedies to permit damages for emotional or economic abuse would be more effective in promoting women's economic security.

\section{Conclusion}

This Article began with a quotation from scholars in the area of cybersecurity. They state that cybersecurity requires "organizational, legal, economic, and social" aspects. ${ }^{355}$ In sum, because our national computer network will never be "safe" from hackers, they argue, the goal of the system should be one that is secure because it is resilient and can withstand, recover, and be strong in the face of breaches of security. ${ }^{356}$ Similarly, our legal system and funding schemes could benefit from focusing on supporting the resiliency of persons subjected to abuse-what I call securitywhich encompasses organizational, legal, economic, and social aspects that help the person subjected to abuse fortify her liberty, dignity, and agency.

Current domestic violence policy, with its limited goal of safety-primarily focused on short-term physical separation to decrease physical intimate partner violence-is both too broad and too narrow a goal. It is too broad a goal because actions taken against the will of the woman subjected to abuse may actually increase her risk of abuse rather than make her safe. In addition, physical separation can also increase abuse. On the other hand, it is too narrow a goal, because the safety paradigm fails to recognize and respond to all forms of domestic abuse, all forms of harm from such abuse, other responses that are not focused merely on short-term physical

350. See id. at 715-16.

351. Id. at 716 (quoting Cal. Penal Code $\$ 13700$ (a) (West 2005)).

352. See id. at 735-53.

353. Carey states that most successful intentional infliction of emotional distress claims were based on actual or threatened physical abuse. See id. at 702.

354. See id. at 754-55.

355. Singer \& Friedman, supra note 1 , at 36.

356. See id. 
separation, and the decision making capabilities of the woman subjected to abuse.

Instead, this Article argues for domestic violence policy, which shapes the civil legal system and government funding criteria, to focus on security. Security incorporates all forms of abuse, including physical, sexual, emotional, psychological, and economic; focuses on all harms that result from these varying forms of abuse; identifies short- and long-term responses that enhance the economic, housing, health, and relationship security of the person subjected to abuse because of the connection between such security and the decrease of domestic violence; and ensures that the person subjected to the abuse is the decision maker as to the appropriate responses to the abuse, because her agency and dignity have a positive relationship to her satisfaction with her life and the recurrence of domestic violence.

As stated earlier, the domestic violence movement is at a choice moment where changing from a safety paradigm to a security paradigm could be beneficial to persons subjected to abuse. A security paradigm could be more effective in identifying and remedying all forms of abuse and the harms from abuse, as well as achieving the goals of addressing intimate partner violence, because the domestic violence legal, policy, and funding systems would address domestic violence in the way that the person subjected to domestic violence would like to address it. Such goals, weighed in the context of her other goals-such as continuing her relationship, achieving economic stability, evaluating her safety, and protecting her children-may result in her choosing to eliminate, to decrease, or to tolerate a measure of the domestic violence. A shift from safety to security would provide state and institutional short- and long-term options to better address all forms of intimate partner abuse beyond physical violence; better address all harms of intimate partner abuse; and enhance effective responses to intimate partner abuse by supporting the agency of persons subjected to abuse, by supporting their community connections and increasing their social capital, and by increasing their access to economic, housing, and health resources. 
